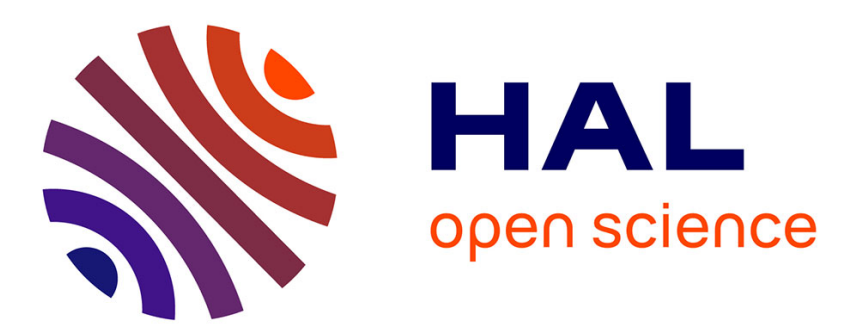

\title{
Blockholder Leverage and Payout Policy: Evidence from French Holding Companies
}

Sereeparp Anantavrasilp, Abe de Jong, Douglas V. Dejong, Ulrich Hege

\section{To cite this version:}

Sereeparp Anantavrasilp, Abe de Jong, Douglas V. Dejong, Ulrich Hege. Blockholder Leverage and Payout Policy: Evidence from French Holding Companies. Journal of Business Finance and Accounting, 2020, 47 (1-2), pp.253-292. 10.1111/jbfa.12415 . hal-03048905

\section{HAL Id: hal-03048905 https://hal.science/hal-03048905}

Submitted on 9 Dec 2020

HAL is a multi-disciplinary open access archive for the deposit and dissemination of scientific research documents, whether they are published or not. The documents may come from teaching and research institutions in France or abroad, or from public or private research centers.
L'archive ouverte pluridisciplinaire $\mathbf{H A L}$, est destinée au dépôt et à la diffusion de documents scientifiques de niveau recherche, publiés ou non, émanant des établissements d'enseignement et de recherche français ou étrangers, des laboratoires publics ou privés. 


\section{"Blockholder Leverage and Payout Policy: Evidence from French Holding Companies"}

Sereeparp Anantavrasilp, Abe de Jong,

Douglas V. DeJong and Ulrich Hege 


\title{
Blockholder Leverage and Payout Policy: Evidence from French Holding Companies*
}

\author{
Sereeparp Anantavrasilp $^{1} \quad$ Abe de Jong $^{2} \quad$ Douglas V. DeJong $^{3} \quad$ Ulrich Hege $^{4}$
}

October 2019

\begin{abstract}
This paper focuses on dominant owners' use of leverage to finance their blockholdings and its relationship to dividend policy. We postulate that blockholder leverage may impact payout policy, in particular when earnings are hit by a negative shock. We use panel data for France where blockholders have tax incentives to structure their leverage in pyramidal holding companies and study the effect of the financial crisis in 2008/2009. We find no difference in payout policy and financial behavior during the 1999 to 2008 period between firms with levered owners and other firms. However, in the years 2009 to 2011 following the crisis, dividend payouts increase in proportion to pyramidal debt of dominant owners. We inspect pyramidal entities individually and find that on average only $60 \%$ of dividends are passed through to the ultimate owners, with the rest predominantly used to meet debt service obligations of the pyramidal entities.
\end{abstract}

Keywords: payout policy, blockholders, concentrated ownership, leverage, blockholder private leverage, margin loans, insider pledging, pyramids, financial crisis.

JEL classification: G32, G34, G35.

\footnotetext{
${ }^{1}$ EY and Department of Finance, Rotterdam School of Management, Erasmus University, PO Box 1738, 3000 DR Rotterdam, Netherlands.

2 Department of Banking and Finance, Monash University, 900 Dandenong Road, Caulfield East, 3145

Victoria, Melbourne, Australia and Department of Finance, Rotterdam School of Management, Erasmus University, PO Box 1738, 3000 DR Rotterdam, Netherlands.

3 Tippie College of Business, University of Iowa, Iowa City, IA 52242, USA, e-mail: douglasdejong@uiowa.edu

4 Department of Finance, Toulouse School of Economics, 21 Allee de Brienne, 31015 Toulouse Cedex 6, France, e-mail ulrich.hege@tse-fr.eu.

* The authors are grateful for helpful comments from Nittai Bergman, Eli Berkovitch, Henrik Cronqvist, Ingolf Dittmann, Edith Ginglinger, Ronen Israel, Meziane Lasfer, Erik Lie, Roni Michaely, Giovanna Nicodano, Urs Peyer, Kristian Rydqvist, T.J. Wong, and Yishay Yafeh and from an anonymous referee, as well as from seminar participants at Aalto, CUHK, ESMT, HEC Paris, IDC Herzliya, Tilburg University, and at various conferences. An earlier version (based on a different sample period prior to the global financial crisis) was circulating under the title "Blockholders and Leverage: When Debt Leads to Higher Dividends". The authors acknowledge excellent research assistance from Mounir Bendouch. Douglas DeJong thanks the Rotterdam School of Management, Erasmus University and CentER, Tilburg University for their support. Ulrich Hege thanks the European Research Council, ERC FP7 grant No.

312503-SolSys, the ANR, grant ANR-17-EURE-0010 under the Investissements d'Avenir program, and TSE-P for funding.
} 


\section{Introduction}

Blockholders sometimes use leverage to finance their dominant equity stake in publicly listed companies. This paper explores the use of private leverage by controlling shareholders and the effects of this leverage on company policies, dividends and investment. To the best of our knowledge, this question has not been addressed before. ${ }^{5}$ The extensive literature on the role of blockholders implicitly assumes that owners use deep pockets to finance their controlling share blocks; blockholders, however, use debt financing for a number of reasons, such as wealth limitations or tax optimization. ${ }^{6}$ The use of blockholder leverage, in hidden or transparent form, has recently come under scrutiny in a number of high-profile cases. For example, Casino, one of the largest French food retailers, was under attack by short sellers since 2018 over concerns about high leverage in its pyramidal holding companies, forcing it to sell assets and to seek limited bankruptcy protection in May 2019 (Financial Times, 31 July 2019). Other French groups also made headlines in recent years over blockholder leverage, ${ }^{7}$ as did companies in other jurisdictions including the U.S., even though the institutional context is often substantially different from that explored in our paper. ${ }^{8}$

In our investigation, we focus on the link between blockholders' debt exposure and the dividend payout policy in times of crisis, when the need of the dominant owner for cash dividends to service debt may influence corporate decisions. We find that, in difficult times, companies exposed to blockholder leverage are reluctant to cut dividends.

Data availability presents a major challenge given the privacy of information on personal debt, despite a renewed regulatory interest to understand the consequences of debt financing (Financial Stability Board, 2015). We focus on France because much of the leverage of large shareholders is in fact structured in holding vehicles. France's specific institutions and personal tax rules convey considerable advantages if levered owners organize their leverage in these holding companies. Tax costs of using holding companies are negligible, and tax rules discourage the use of

\footnotetext{
${ }^{5}$ Dou, Masulis, and Zein (2019) show that insider share pledging may lead to reduced risk-taking.

${ }^{6}$ For example, according to court filings, Ronald S. Lauder, the owner of a large block in cosmetics and fashion group Estée Lauder Companies, uses debt apparently for tax motives: "Nearly $\$ 400$ million of that stock [worth $\$ 600$ million] is pledged to secure various lines of credit. Many financial planners consider it imprudent for principal shareholders in a company to borrow against their stock. But it remains a popular way for wealthy taxpayers to get cash out of their holdings without selling and paying taxes" (New York Times, Nov. 26, 2011).

${ }^{7}$ In August 2019, the controlling blockholder's shares in publishing and retail conglomerate Lagardère were reportedly worth less than the personal bank loans secured by them (Financial Times, 27 August 2019). When Carrefour, a large multinational retailer, experienced floundering sales in 2011, observers urged it to cut its dividend, but Nomura analysts cautioned: "Since Carrefour's core shareholders' (Blue Capital) investment in Carrefour is 80 percent debt financed, we question whether they can accept a sharp reduction in dividend." (Reuters November 17, 2011, http://www.reuters.com/article/2011/11/17/uscarrefour-analysis-idUSTRE7AG0M220111117). Telecom operator Altice, owner of Cablevision and other US assets, came under duress in 2017 over concerns about its leverage and the use of blockholder leverage by its founder.

${ }^{8}$ Examples include Steinhoff International of South Africa, engulfed in an accounting scandal in 2017 that led to a $90 \%$ share price drop and a fall in the value of the largest shareholder's equity to $25 \%$ of the blockholder loan; WorldCom whose CEO Bernie Ebbers had repeatedly used margin loans on his personal equity before the company collapsed in 2001; Portuguese bank Espirito Santo that similarly collapsed in 2014; and Chinese manufacturer Geely when it acquired a large equity block in Daimler-Benz in early 2018 on margin loans.
} 
pyramidal mixed companies that combine financial holdings with operating investments. Furthermore, holding companies are quite transparent, i.e., we observe ownership structure, financial structure and payout policy of privately-owned as well as publicly listed companies, including holding companies. Thus, while we cannot observe the use of private leverage comprehensively, fiscal incentives and the relative transparency of holding vehicles provide a starting point to investigate its consequences. In France, a large majority of listed firms are controlled by dominant owners, as is the case in a majority of countries (e.g., LaPorta, Lopez-di-Silanes, Shleifer, 2000; this observation does not hold for the U.S., the UK, and certain other countries).

We begin by carefully mapping the use of pyramids and pyramidal leverage in France, our proxy for the use of private leverage by controlling blockholders. A majority of listed companies are characterized by shareholder concentration. We find that a majority of publicly listed companies are organized as pyramids. We show the phenomenon of pyramidal debt to be wide-spread: a majority of pyramidal holding companies use some (albeit moderate) leverage, and pyramids lead to a mean increase of the dominant owner's leverage exposure by $12.1 \%$ or $35.2 \%$, depending on which of our two measures of pyramidal leverage is used. On the whole, we find that the use of pyramidal debt is wide-spread, but that blockholder leverage on average is moderate.

We then investigate the impact of blockholder leverage on dividend payouts. We do so in two steps. We first analyze dividend payouts in our panel by focusing on the cross-sectional comparison, controlling for all the usual variables that are known to influence payout, and then look at the shock of the financial crisis starting in 2008. In our first investigation, the cross-sectional panel study prior to the financial crisis, we find no difference in payouts between companies with levered blockholders and those without blockholder leverage. This finding may be due to the fact that French holding companies overall make a relatively conservative use of leverage, according to our data. From a strict econometric point of view, this finding offers reassurance that we are looking at similar sets of firms in the treatment and control sample when exploring the crisis impact. An important caveat is that controlling blockholders could also use other sources of personal income (that we do not observe) to pay for holding company debt or their consumption, and not just the dividends received from the companies they control; we do not observe, however, equity injections in holding companies that would indicate such substitution effects.

However, we find strong support for the hypothesis that blockholder leverage affects payout policy in difficult times. The 2008/2009 financial crisis was an exogenous shock affecting the global economy in almost all developed economies that led to severe cuts in dividend payouts in listed companies worldwide and also in France (David and Ginglinger, 2016). Crucially, however, the shock should affect companies differently according to the dominant blockholder's exposure to private blockholder leverage; we use this heterogeneous intensity of reaction to 
the treatment (the financial crisis) for our identification. We find that firms with pyramidal leverage maintain high dividend payouts even when cash flows are plummeting and peers are cutting their payouts.

To look for additional evidence on the causal link between blockholder leverage and the difference in crisisinduced payout behavior, we take a closer look at the flow of funds within pyramids for additional evidence that payout decisions are explained by pyramidal debt. Inspecting pyramids on an entity-by-entity basis, we find that the fraction of dividends consumed in each holding company and not passed on to the next entity increases strongly in our measures of the importance of debt service in that holding company. Dominant owners ultimately receive less than 60 percent of the cash that operating companies make available to them, a fraction that decreases strongly in our measures of pyramidal debt.

Finally, we consider the robustness of our finding and extensions. We analyze the consequences of blockholder leverage for the real policies of the company, but do not find that a dividend increase triggered in times of duress by a blockholder's leverage has a measurable effect on corporate investments or risk-taking. We also demonstrate the robustness when using more conservative measures of pyramidal debt, explore Almeida and Wolfenzon's (2006) theory of dividend payouts in pyramids, and take into account double voting rights that in France may considerably enhance the discrepancy between voting and cash flow rights. None of these robustness checks alter our main findings.

To the best of our knowledge, our paper is the first to attempt to study the impact of the private leverage of dominant shareholders via holding company debt or similar vehicles. A similar issue arises when dominant owners use margin loans where the equity stake serves as collateral (also known as insider pledging of company stock), as our introductory examples show; unlike holding company debt, however, these loans are rarely observable to researchers. Our paper is related to various strands of the literature that we discuss in more detail in the next section. It is obviously related to the large literature on payout policy, in particular to work on payout policy in companies with dominant blockholders. This literature is characterized by two conflicting hypotheses, expropriation vs. substitution. Our paper adds to this literature with its analysis of the role of blockholders' private leverage. Our paper is also related to literature on payout policy and shareholder-bondholder conflicts, in particular for firms close to financial distress. Our paper contributes to this literature with the insight that the private leverage of blockholders may exacerbate shareholder-bondholder conflicts in times of financial distress. Finally, we contribute to the papers on financial structure and payout policy in pyramidal structures with the insight that blockholder leverage may be an important determinant of payout decisions in times of financial distress.

The paper is organized as follows. Section 2 presents the literature and discusses our hypotheses. Section 3 describes the study's design and data. Section 4 outlines our main results. Section 5 presents further evidence on how 
dividends are passed through pyramidal entities. In Section 6, we look at various robustness tests and extensions, and Section 7 concludes.

\section{Literature and Hypotheses}

We briefly discuss the various strands of the literature to which our paper is related, on payout policy and blockholders, on shareholder-creditor conflicts under financial duress, and on pyramids.

Regarding the role of blockholders in corporate payout policy, existing work supports two contrasting views on the question whether the presence of large owners should lead to lower or to higher dividend payouts compared with widely held companies. The first view (sometimes referred to as the expropriation hypothesis) argues that the level of payouts is lower since the dominant shareholder gets only a fraction of the cash benefits compared with her exclusive benefits of control over retained earnings. This effect should increase in the discrepancy between control and cash flow rights (Burkart and Lee, 2008; Claessens et al., 2002; Adams and Ferreira, 2008). There is substantial evidence supporting this view (e.g., La Porta et al., 2000). In the alternative view, dominant owners commit to a stable dividend level in order to offset market doubts about expropriation risk. According to this view (dubbed the substitution hypothesis by La Porta et al., 2000), the positive stock market value effect dominates the potential benefits from retained earnings. Faccio, Lang, and Young (2001) present empirical evidence supporting this view. In light of these ambiguous hypotheses and tests, it seems fair to summarize that there is no dominant explanation on the impact of ownership concentration on payout policy.

Our paper is also related to the literature on payout policy and shareholder-creditor conflicts. According to standard capital structure arguments, dividend payments can be used to expropriate wealth from debt holders by increasing a firm's net debt and hence making its debt riskier (Allen and Michaely, 2003). DeAngelo and DeAngelo (1990) show empirical evidence that firms in financial distress are reluctant to cut dividends. Chu (2017) finds that firms reduce dividend payouts when blockholders and important lenders internalize the negative value effects that dividend payouts create for lenders and, hence, mitigate shareholder-creditor conflicts. ${ }^{9}$ Chu (2017) also finds that this mitigation is particularly pronounced when firms are in financial distress. Gilje (2016) presents evidence, using exogenous leverage shocks following commodity price jumps in the oil and gas industry, in particular, for purposes of identification, that firms with heightened shareholder-creditor conflicts following sudden leverage increases take less risk in their capex spending.

\footnotetext{
${ }^{9}$ See also Brockman and Unlu (2009) for international evidence.
} 
In spite of our focus on corporate holding companies, the relationship of our paper to the literature on pyramids is rather limited. In France, holding companies are typically private vehicles of blockholders with assets dominated by the equity stake in a single listed company; they exist for reasons mainly based on taxes (see the next section) that seem to suggest that the presence of a holding company can lead to higher dividend payouts. ${ }^{10}$ By contrast, the literature on pyramids mainly focuses on diversified business groups or conglomerates organized under umbrella holding vehicles. For example, Almeida and Wolfenzon (2006) argue that diversified business groups organize capital accumulation through a listed holding company as a substitute for capital markets with frictions, and argue that listed companies in such pyramidal structures are likely to have lower payouts and retained earnings funding investments in other business ventures. ${ }^{11}$

Besides the various strands of the literature discussed above, prominent general theories on capital structure and corporate payouts provide guidance when formulating hypotheses for our analysis of the payout consequences when dominant owners use private leverage to fund their equity stakes, in particular theoretical arguments on the role of debt to force companies to disgorge cash (e.g., Jensen, 1986) and the conflicts surrounding and consequences of financial distress (e.g., Myers, 1977). The dominant shareholder must assure the solvency of her holding vehicles, and she will use the dividend payout as a source of funding to service her debt. As long as the dividends paid by the operating company are sufficient to cover the owner's pyramidal debt, pyramidal debt should not affect payout policy. However, if the level of pyramidal debt is high, then we expect the dominant owner to push for higher dividends. While this effect should be present only for highly levered owners, we expect it be more widely observable in the case of an adverse financial shock to the operating company. Then, leveraged ownership creates a disparity between the dominant owner's use of cash and the needs of the company and other shareholders and potentially heightens shareholder-creditor conflicts. Therefore, we postulate that dividend payouts should increase in the use of pyramidal debt by dominant owners: Pyramidal debt has a positive effect on dividend payouts when operating company cash flow is hit by an adverse financial shock.

\footnotetext{
${ }^{10}$ Holding companies can be used as a tax shelter shielding dividends from personal income tax. Given tax neutrality of pyramids (as is the case in France), pyramidal structures can then accommodate diverging dividend preferences: dividends can be paid to cater to dispersed shareholders, while dominant owner with lower cash preferences can avoid immediate taxation.

${ }^{11}$ There is relatively little prior work on payouts and capital structure in pyramids. Gopalan, Nanda, and Seru (2007) show that in Korean business groups dividends are used to finance investments in new subsidiaries. A small number of papers address the question how business groups allocate debt between parent firms and subsidiaries (Bianco and Nicodano, 2006; Luciano and Nicodano, 2014) from the perspective of the internal capital market of the group. Bertrand, Mehta, and Mullainathan (2002) document that in business groups wealth is transferred to controlling shareholders. None of these papers investigates the link between pyramidal debt and dividends.
} 


\section{Holding Companies in France: Background, Methodology and Summary Statistics}

\subsection{Institutional Background on Holding Companies in France}

France presents an ideal laboratory to investigate the role of pyramidal leverage in the relationship between large and small shareholders. France is a developed market, with the largest percentage of foreign stock ownership among the large European economies, and with a high degree of ownership concentration in listed firms. Structuring a large equity block in a holding vehicle, i.e. creating a pyramid, offers several potential benefits for blockholders but entails little administrative cost. As this institutional set-up suggests, pyramids are widely used and deeply embedded.

According to the tax regime that has essentially been stable since 1965, a holding company receives almost full tax credit for the corporate income tax paid by the operating company or a subordinate holding vehicle, meaning that pyramids in France are essentially tax neutral (so-called "régime des sociétés mères"). This corporate tax credit, however, is conditional on holding the share block for at least two years ${ }^{12}$ and on holding at least $5 \%$ of the equity (10\% until 2000); thus, only long-term investors that are significant shareholders benefit from the avoidance of double taxation. The tax credit is only approximately complete because the administration costs of a holding company remain taxable, at a level of the true administrative cost of the entity or $5 \%$ of its revenue, whichever is smaller. This creates a tax incentive to keep the true administrative costs of holding vehicles at a minimum and to structure them as pure financial holding entities unencumbered by any real assets or activities that would lead to higher administrative costs and a smaller tax credit. Thus, tax reasons can explain why holdings companies do not typically consist of a portfolio of equity blocks and operating assets as is the case in business groups that are prevalent in other countries.

Using a pyramid to structure an equity block offers several advantages in France. First, if the large shareholder has issued some debt, structuring the debt in a holding company allows the interest expense to be deducted against the dividend payouts that are subject to personal income taxes. Thus, the prevailing tax regime suggests that large share blocks financed with debt will be organized in pyramids. Second, pyramids decouple the decision of a listed operating company to pay dividends from the decision of a large blockholder to receive the dividend. That is, blockholders can use pyramidal holdings as a tax shelter; they will only incur the corresponding personal income tax on dividends when the dividends received by the holding company are later transferred to the ultimate owner. Therefore, since holding companies are neutral regarding corporate taxes, increasing the use of debt

\footnotetext{
${ }^{12}$ A declaration of intent to hold the shares for more than two years is considered sufficient. Breach of the declaration of intent through an earlier sale carries no other penalty besides back taxes. Thus, the tax neutrality of a new blockholder is in practice effective immediately and not after a two-year waiting period.
} 
in a pyramid procures no tax savings, neither for personal nor corporate taxes. ${ }^{13}$ Third, holdings are the only practicable way in France to engineer a disparity between voting and cash flow rights. For all practical purposes, dual class shares are not allowed. France allows double voting rights for long-term investors, but their role is different and their impact limited, as our robustness results for double voting rights show (see Section 6.4). In addition, holding companies jointly held by multiple blockholders, such as family members, provide a vehicle for the multiple blockholders to vote as one block in corporate decisions.

Finally, French regulations require all companies, public and private, to file their unconsolidated financial statements on an annual basis. French regulations also require all companies, public and private, to register their list of important shareholders and listed companies to disclose important changes in shareholdings and their holding structure. ${ }^{14}$ Thus, the ownership structure, financial structure and payout policy of privately-owned as well as publicly-listed companies, including holding companies, are accessible.

\subsection{Measures of Pyramidal Leverage and Control}

In this section, we present a simple example to introduce our key variables for debt and control. Pyramids can be complex and France is no exception. Appendix A presents a full description of the design and algorithms that address cross-holdings and parallel ownership chains.

The Figure 1 example features an operating company, two holding companies and a dominant owner. All entities in the pyramid are vertically aligned, and the two holding companies have no other assets. Ms. $X$ dominates the company $\mathrm{OpCo}$ by controlling $30 \%$ of its equity by means of two holding companies: HoldCol owns $30 \%$ of OpCo; HoldCo2 owns $60 \%$ of HoldCo1; and Ms. X owns $70 \%$ of HoldCo2. Ms. X's cash flow rights are conventionally measured by the product $0.7 \cdot 0.6 \cdot 0.3=0.126$, her claim on $O p C o$ 's dividends. In measuring control rights, we apply the same product rule but convert majority stakes, 0.6 and 0.7 , to full control, i.e. 1.0. Thus, her control rights are $1.0 \cdot 1.0 \cdot 0.3=0.3$. The measure of the disparity between control rights and cash flow rights that we call the control wedge is the ratio of control rights/cash flow rights, calculated as $0.3 / 0.126=2.38$.

\footnotetext{
${ }^{13}$ That is, the same tax advantage can be achieved by simply sheltering dividends in holdings, without using debt. On the other hand, conditional on using personal debt, it is tax-efficient to structure it as pyramidal debt.

14 Per French corporate laws, the following key thresholds give rise to discontinuous changes in control rights: 1) $33 \%$ : This level of control grants veto rights. It also triggers the mandatory bid rule, i.e. any owner passing through the $33 \%$ threshold is required to launch a full and unrestricted takeover offer; 2) $40 \%$ : Control is presumed if one shareholder has at least $40 \%$ of voting rights, directly or indirectly, and is the largest shareholder (according to article 355-1 of French securities law per Bloch and Kremp, 2001); 3) 50\%: This level constitutes majority voting rights (or legal control) and triggers notification to the French authorities; 4) 67\%: Reverse of the 33\% rule, i.e. the ability to block any veto rights by other shareholders. This level is also the highest conditional takeover offer allowed under French law (restricted offers are not allowed in France).
} 
Our focus is on the dominant owner's exposure to leverage in the various entities of the pyramid. We use two measures to aggregate the leverage throughout the various entities of the pyramid. We explain the two measures using our example. HoldCo1 is financed with $35 \%$ debt and $65 \%$ equity and HoldCo2 is financed with $20 \%$ debt and $80 \%$ equity. OpCo itself is $10 \%$ debt-financed. We denote the leverage ratio in pyramidal entity $k$ by $l_{k}$, so that in our example $l_{0}=0.1, l_{1}=0.35$ and $l_{2}=0.2$. In this setting, OpCo needs to pay a sufficient dividend so that HoldCol and HoldCo2 can service their debt. Ms. X's effective claim on $O p C o$ 's cash flows is reduced as a consequence.

Focusing on holding company debt, our first measure of pyramidal leverage, which we call average leverage, is just the mean leverage ratio of all the holding entities in the pyramid. In the example, we have an average leverage of $(0.35+0.2) / 2=0.275$. More generally, if the pyramid consists of $n$ holding companies, $k=1$, $2, \ldots, n$, average leverage is defined as $\frac{1}{n} \sum_{k} l_{k}$.

Our second measure, equivalent leverage, is motivated by the concern that average leverage may underestimate the dominant owner's true debt exposure. Such is the case when several levered holding companies are vertically superimposed on the operating company, as in our example. Ms. $X$ 's cash flow profile from her stake in $O p C o$ is successively exposed to the leverage in the pyramidal layers. Equivalent leverage determines the leverage ratio that would give Ms. $X$ the same cash flow profile if she were to hold her stake in $O p C o$ and her pyramidal debt in a single levered holding company. In our example, equivalent leverage is calculated as $l_{0}+\left(1-l_{0}\right) l_{1}+\left(1-l_{0}\right)(1-$ $\left.l_{1}\right) l_{2}=0.1+(1-0.1) \cdot 0.35+(1-0.1) \cdot(1-0.35) \cdot 0.2=0.532 .{ }^{15}$ Thus, this computation aggregates Ms. $X$ 's full leverage exposure in the entire pyramid. More generally, if the pyramid consists of $n$ vertically stacked holding companies, $k=1,2, \ldots, n$, equivalent leverage is defined as $l_{0}+\left(1-l_{0}\right) l_{1}+\left(1-l_{0}\right)\left(1-l_{1}\right) l_{2}+\left(1-l_{0}\right)\left(1-l_{1}\right)\left(1-l_{2}\right) l_{3}+$ $\ldots+\left(1-l_{0}\right)\left(1-l_{1}\right) \cdot \ldots \cdot\left(1-l_{n-1}\right) l_{n}$. Equivalent leverage collapses the dominant owner's pyramidal leverage to a single leverage ratio, by hypothetically reallocating all debt in the pyramid at the operating company level (and assigning zero leverage to all holding companies), in such a way that the ultimate owner's effective exposure to leverage is measured equivalently to the actual combined leverage of the pyramid structure (or of the dominant chain of control in case of multiple chains).

We have missing information on the capital structure for $32.7 \%$ of the reported pyramidal holding companies, with a marked increase in the second half of the sample period, due to an increase in foreign-based holding companies and lower compliance. When calculating the values for the two measures of pyramidal debt, we

15 For an intuition for the logic behind equivalent leverage, let $r_{D}$ be the cost of debt (assume $r_{D}$ is the same for all entities in the pyramid). If $O p C o$ pays a dividend yield of $x$, then HoldCol receives $0.3 \cdot x$ and, after paying interest, has earnings (ROE) of $0.3\left(x-l_{1} r_{D}\right)$. If HoldCol pays out all of its earnings as dividends, then HoldCo2 receives $0.6 * 0.3\left(x-l_{1} r_{D}\right)$ and, after paying interest, has earnings (ROE) of $0.6 \cdot 0.3\left(x-l_{1} r_{D}-\left(1-l_{1}\right) l_{2} r_{D}\right)$. If all of it is paid out, the dominant owner receives $0.7 \cdot 0.6 \cdot$ $0.3\left(x-l_{1} r_{D}-\left(1-l_{1}\right) l_{2} r_{D}\right)$, whereas she would receive $0.7 \cdot 0.6 \cdot 0.3 \cdot x$ if there was no pyramidal debt. 
assume that the leverage in a holding company in the pyramid corresponds to the average of the holding companies in the same pyramid when no such data is available. Thus, our procedure ensures that the treatment of missing observations is neutral for our estimates of both leverage measures, average and equivalent.

\subsection{Data and Variables}

Our starting point is the set of all publicly listed companies on Euronext Paris as of December 31, 2012. Our initial sample includes firms from all three tiers of the Paris market, about 1,170 companies. We then impose the filter that each company be continuously included in the WorldScope database over the period 1999-2011. This criterion substantially reduces our sample; the final sample consists of 240 firms. We refer to each of these publicly listed companies as an operating company. Next, we collect the complete ownership information in every year for all holding companies, public and private. This information is available from the Dafsaliens database that also documents validation dates (Dafsaliens was set up by large French financial institutions to provide precise ownership information). Starting from the operating company, we use Dafsaliens to trace the ownership of the owners of the operating company and continue this process until we have traced the entire ownership structure to the dominant owners. We trace ownership across all ownership classes, individual/family, public company, unlisted private company and state.

In accordance with La Porta, Lopez-de-Silanes, and Shleifer (1999), Claessens, Djankov, and Lang (2000), Faccio and Lang (2002) and others, we require that a shareholder possess a substantial level of control (i.e. voting rights) in order to qualify as a dominant owner. The typical threshold used in the literature is $20 \%$. To be consistent with the literature and allow comparisons with prior findings, we use the same $20 \%$ threshold in our baseline. In each operating company, we verify whether the largest ultimate owner exceeds this threshold. If no shareholder has a control right stake of $20 \%$ or more, the company is considered as widely held. Otherwise, we identify the ultimate owner with the largest control right stake and we refer to this ultimate owner as the dominant owner.

We capture the discontinuous character of control rights by using concepts similar to those adopted in Almeida et al. (2011) and assume the dominant shareholder has absolute control over the operating company if she has a majority of votes. That is, we convert effective control rights of greater than $50 \%$ in any entity into full control of $100 \%$. The other stakes are then allocated zero control rights. Again, more complex cases with several control chains are discussed in the Appendix A.

From the Diane database (the French component of Bureau van Dijk's Amadeus database), we collect the unconsolidated financial statements for private unlisted and for listed companies in the ownership chain for 1999 to 2011. The unconsolidated financial data provided by Diane eliminates the effect of group debt and focuses the 
analysis on the capital structure of the firm itself. For the sample of 240 operating companies, we use their consolidated financial statement information from WorldScope. ${ }^{16}$

The richness of the Dafsaliens and Diane information offers an important advantage over annual reportbased data and company handbooks used in most previous works such as La Porta, Lopez-de-Silanes, and Shleifer (1999) and Faccio and Lang (2002), which cover only ownership information of public companies.

\subsection{Firm Characteristics, Ownership Structure and Pyramids}

Table 1 describes summary statistics of ownership structure and firm characteristics of the 240 French operating companies, yielding 2,880 observations in our 2000-2011 window (dropping 1999 as the regressions use lagged variables), of which 2,160 before the crisis and 720 after the outbreak of the crisis. ${ }^{17} \mathrm{We}$ find that in the pre-crisis period $2000-2008$, only $26.1 \%$ of operating companies are widely-held, and $73.9 \%$ of the firms have a blockholder who satisfies the inclusion threshold of $20 \%$. Moreover, in $44.9 \%$ of our pre-crisis sample, dominant shareholders use pyramids to control the operating company. This high frequency of pyramid-controlled firms, substantially higher than the 26\% frequency that La Porta, Lopez-de-Silanes, and Shleifer (1999) and Faccio and Lang (2002) report for France, is explained by the inclusion of private holding companies. By contrast, earlier studies on pyramids in France classify firms as pyramids only if at least one of the holding companies in the pyramidal structure was a public company. ${ }^{18}$ We find that only less than one quarter of pyramidal structures contain a public company (not reported in tables). While perhaps an inevitable restriction in cross-country studies, limiting the pyramid definition to only structures with listed holding entities leads to a substantial undercount of the use of pyramids in at least the case of France.

Dominant owners are classified by type in Table 1 (individual/family, firm, and state and others). Approximately forty-eight percent of operating companies are controlled by either a family or an individual, roughly in line with earlier studies. Corporate owners comprise $17.2 \%$ of dominant owners in the pre-crisis sample.

Table 1 also provides an overview of key financial characteristics for the companies in our sample, broken down by type of control and owner, that allows us to see whether firms are comparable across ownership types. In terms of size, measured by total assets, widely-held firms are only slightly larger than firms with dominant owners, and they have about the same sales growth rate as block-owned firms, whereas companies in pyramids have slower

\footnotetext{
${ }^{16}$ If any of the 240 companies control subsidiaries, the net financial position of the subsidiaries and operating company is reflected in the operating company's consolidated financial information.

${ }^{17}$ In order to describe the longer term developments after the crisis, Table 1 also includes the 2012-2014 and 2015-2017 descriptives of the 720 firms in the post-crisis sample.

${ }^{18}$ La Porta, Lopez-de-Silanes, and Shleifer (1999); Faccio and Lang (2002); Ginglinger and Hamon (2012).
} 
growth. Widely held firms have somewhat higher operational risk and a higher frequency of loss years. Capex spending and Tobin's Q are comparable across all categories, as are cash flows and return on assets. Leverage is defined as total debt obligations, scaled by book value of total assets, with operating companies in pyramids having marginally higher ratios. Sales growth is the two-year growth rate of sales. We measure dividends relative to cash flow. ${ }^{19}$ Relative to the full sample, operating companies with pyramidal ownership pay dividends comparable to those of widely-held firms, slightly above the full sample means, and blockholder-controlled firms without pyramids have lower dividend payouts. Comparing the average dividends before and after the crisis for blockholder and pyramidal ownership, Table 1 shows that the dividends scaled by firm size have decreased, while a large fraction of cash flows have been paid out. The frequency of loss firms and the level of operating risk are comparable across the crisis subsamples, with operating companies in pyramids slightly lower. Pyramidal blockholder-controlled firms are not different from other firms in terms of financial constraints and their position in the firm life cycle (DeAngelo et al. (2006)'s variable retained earnings/equity), but their stock market liquidity is lower (unsurprisingly for concentrated ownership). The industry breakdown shows a wide mix of industries in the full sample as well as in the subsamples of block owner-controlled and pyramid-controlled operating companies. Overall, widely held firms, firms with blockowners, and firms with blockowners using pyramids are roughly comparable.

\subsection{Summary Statistics of Pyramidal Leverage}

In Table 2, we present summary statistics for pyramid-controlled operating firms (i.e., firms with a dominant blockholder exceeding $20 \%$ of ownership and a pyramidal structure), for the pre-crisis and the post-crisis periods, and an analysis of changes due to the onset of the crisis. We continue our analysis with a sample of 970 firm-years in block-owned pyramids, for which we calculate the control wedge as well as the two debt measures for the pyramidal structure. For this sample, $34.4 \%$ of holding companies on average have missing data, and the median holding company has no missing data.

We report an expansion of the summary statistics for the financial characteristics shown in Table 1 for pyramid-controlled operating firms, showing average, median, and standard deviation. Not surprisingly, sales growth, capex, Tobin's Q, cash flows all fall, and the frequency of losses rises substantially and significantly with the onset of the crisis. As a consequence, dividends as a fraction of total assets (our main measure) also fall, albeit with weak significance, but not dividends when scaled by cash flows. Table 2 also shows the dominant owner holds on average $37.5 \%$ of the equity (direct ownership) in the operating company (median: $32.8 \%$ ). Pyramidal structures

\footnotetext{
19 We follow common practice and set payout ratios to unity when dividends are paid but cash flows are negative or less than the dividend (e.g. Megginson and Von Eije, 2008).
} 
contain 2.64 layers on average with a median of 2. This measure includes the operating company as a layer. The control wedge with a pre-crisis mean of 2.07 (median: 1.667) measures the control-enhancing effect of pyramids as follows: considering only equity stakes in the pyramidal structure, dominant owners own 1.07 times more voting rights on average than they hold cash flow rights, and it changes little in the post-crisis period. Financial leverage increases with the crisis, both as the standard leverage ratio (financial debt/total assets), and when measured as Net debt/EBITDA.

Our two measures of pyramidal leverage consistently show that pyramidal debt is wide-spread in France, but moderate in size on average. In line with the leverage increase of the operating companies, we also find an increase from the pre-crisis to the post-crisis period. Average pyramidal leverage, which measures the mean debt-asset ratio in all holding companies across a pyramid, has a pre-crisis mean value of $13.5 \%$ (16.7\% post-crisis) but a pre-crisis median value of only $2.1 \%$ (post-crisis $2.4 \%$ ), reflecting a conservative capital structure. The dominant owner's total exposure to pyramidal leverage, however, is larger than indicated by average leverage if several holding companies are vertically stacked. This is the case in a large fraction of pyramidal firms (the average pre-crisis number of layers of holding companies is 1.64 , after subtracting the operating company from the mean of 2.64 layers in total, increasing to 1.83 after the crisis). Equivalent pyramidal leverage, our second measure, transforms debt to an equivalent exposure, and provides a better view of the consolidated leverage exposure of the dominant owner throughout the bottom company and vertical chain of holding entities. The mean (median) pre-crisis equivalent leverage is $39.6 \%(36.7 \%)$, increasing to $45 \%$ (41.4\%) post-crisis. In untabulated numbers, we find that $25 \%$ of the controlling owners of pyramidal firms have a pre-crisis equivalent pyramidal leverage measure of $57.9 \%$ or more. These numbers show the use of leverage in pyramids is significant for some pyramid-controlled firms in France. The distribution for our financial constraints, stock market liquidity and firm life cycle variables among pyramidal firms does not reveal any striking patterns.

\subsection{Stability of Pyramids and Pyramidal Debt}

We investigate whether pyramids and pyramidal debt are persistent over time. We start by collecting the evidence on the time variations in the presence of dominant blockholders. If block ownership is endogenous it should dynamically adjust when the firm's conditions change. ${ }^{20} \mathrm{We}$ inspect the rate of change in block ownership by looking at the two-year changes and find that the ownership classification (widely held, block-non pyramid, blockpyramid) does not change from one year to the next for close to $90 \%$ of firms.

20 See e.g. Demsetz and Lehn (1985), Agrawal and Knoeber (1996), Cronqvist and Fahlenbrach (2009). 
We also investigate whether pyramidal structures exhibit the same persistence that we find for the dominant owners and their blockholdings. We find that pyramids and their holding vehicles are stable over time. We draw a random sample of 100 holding companies and investigate the year they were founded. On average, the holding companies at the beginning of the sample period in 1999 are already more than 30 years old, less than $10 \%$ were founded in 1990 or later, and the oldest holding company was founded in 1865 . The large number of companies controlled by families (54.9\% of the pyramidal firms versus $37.7 \%$ for the non-pyramidal firms with a controlling blockholder, see Table 1) is one of the main drivers of the longstanding nature of the relationship between dominant blockholders and listed operating companies.

As a final verification, we consider the stability of pyramidal debt. While the leverage ratio of pyramidal entities fluctuates from one year to the next, we find that the debt exposure of firms with high pyramidal leverage compared to firms with little pyramidal leverage is persistent. To analyze the autocorrelation of pyramidal debt, we sort our sample of firms with pyramid control into quartiles according to their pyramidal leverage, using our two leverage measures. When analyzing the persistence of their position relative to all pyramidal firms, we find that, measured by equivalent leverage, $86 \%$ of firms remain in the same quartile of pyramidal leverage exposure from one year to the next ( $73 \%$ when we consider average leverage). This high persistence of firms' pyramidal debt exposure is useful for our identification strategy during the financial crisis.

\subsection{Operating Company Debt and Pyramidal Debt}

Finally, we explore the relationship between operating company debt and pyramidal debt. While there is no literature on the capital structure of holding companies with pyramidal debt, we do not expect pyramidal leverage and company leverage to be correlated in a predictable way. ${ }^{21} \mathrm{We}$ investigate the correlation between operating company debt and pyramidal debt. We determine the correlation coefficients between the company leverage and our two measures of pyramidal debt (not tabulated in tables), and find no correlation of the company's leverage ratio with average leverage $(\rho=0.06)$ and a low but reasonable positive correlation with equivalent leverage $(\rho=0.36)$, consistent with our findings for operating company leverage in Table 3, Panel B. This result holds also in untabulated regressions trying to explain the presence of pyramidal leverage, in particular when including variables

\footnotetext{
${ }^{21}$ Standard arguments suggest that if operating company debt is optimized, optimal pyramidal debt should be zero if the dominant owner faces no wealth constraints. Wealth constraints or other motives for pyramidal debt, however, are not obviously correlated with operating company characteristics. Also, dominant owners in our sample are unlikely to self-select to companies according to their risk characteristics or leverage, considering that our blockholders are overwhelmingly families, corporations or government that typically cannot be dissociated from the company history. We cannot rule out that the decision whether to place debt in the operating company or in the pyramidal entities can make a difference for some types of ultimate owners.
} 
that typically explain leverage, such as size, age, tangible assets or past profitability. To conclude, we are unable to explain the choice of pyramidal debt from observable company characteristics. That leaves only unobserved company characteristics, or characteristics of the dominant owners themselves and their choices, as possible determinants of an endogenous relationship between pyramidal debt and dividends.

\section{Pyramidal Leverage and Payout Policy}

\subsection{Identification Strategy}

Our main identification strategy relies on the crisis shock of the financial crisis of 2008/2009 as the basis for a difference-in-difference estimation with expected heterogeneous local average treatment effects, using methodology formally introduced by Imbens and Angrist (1994). The crisis was unexpected and pervasive but firms, when classified according to their exposure to pyramidal debt, are expected to differ in their likely dividend response according to their degree of exposure to pyramidal leverage. In other words, we exploit the fact that the shock (the treatment) incurred during the financial crisis varies according to the heterogeneous pyramidal leverage.

The fact that pyramidal holding companies and their debt levels are stable over time and exhibit a low correlation with company leverage or other company characteristics, is reassuring news from an econometric point of view: it allows us to view the blockholder's private leverage exposure as given and as quasi-randomly assigned (conditional on all controls that we include) when the crisis arrives. Thus, the stickiness of pyramidal debt and the lack of correlation with operating company characteristics appear to validate our approach. ${ }^{22}$

\subsection{Ownership Structure and Dividend Payouts Before and After the Crisis}

Table 3 presents the regression analysis for the dividend policy for all firms over the entire sample period, 20002011. The purpose of this table is to investigate whether the type of ownership structure matters for payout policy, and whether the financial crisis of 2008 has an impact on this relationship. When analyzing the impact of the financial crisis, we take into account that the crisis had an effect on payout policy in France with a delay (David and Ginglinger, 2016), often attributed to the importance of automatic stabilizers; by some measures, the depth of the crisis was only reached in conjunction with the European sovereign debt crisis starting in 2010. Therefore, we consider that the full impact of the crisis was only felt in 2009 and sometimes even later. Indeed, dividends paid in Spring 2009 were still at relatively high levels. We define the dummy variable $d$ PostCrisis that takes a value of one for the years 2009, 2010 and 2011 (company earnings in year $t$ are reflected in dividends in year $t+1$, and hence

\footnotetext{
${ }^{22}$ The conditions of Imbens and Angrist (1994) for the validity of local average treatment effects (relevance, exclusion restriction, (conditional) random assignment, monotonicity) are satisfied.
} 
dividends are measured in the following year). We focus on dividends scaled by total assets (Div/TA) as our dependent variable. Our main findings are robust when using alternative measures of dividend policy (see Table IA.2 in the Internet Appendix).

Panel A of Table 3 shows in the first two lines that the dividend policy of pyramid-controlled firms does not significantly differ from that of widely held firms, whereas firms with blockholders but no pyramidal structure pay less dividends, consistent with the expropriation hypothesis of LaPorta et al. (2000) (the prefix $d$ denotes dummy variables in this and the following tables). When we interact the $d$ PostCrisis dummy with our variables for the presence of blockowners or pyramids, we find that the dividend policy does not change between the pre-crisis and the post-crisis period for the three ownership structures. This means that companies with concentrated shareholdings or holding companies adjust their dividend policies in reaction to the crisis in exactly the same way as do widely held companies. $^{23}$

We also consider whether there is a different dividend reaction to the crisis event for firms exposed to financial distress. In Panel B of Table 3, we use three different measures of financial constraints: the interest coverage ratio used in Chu (2017), the leverage ratio used in Hoshi, Kashyap and Scharfstein (1990), as well as the variable net debt/EBITDA. We define firms to be in financial distress if they belong to the most exposed quartile of sample firms for each of the financial constraint measures (bottom quartile for the interest coverage ratio, and top quartile for leverage ratio and net debt/EBITDA). The results are reported in Table 3, Panel B. Our focus is again on pyramidal firms with a blockholder. We find that the triple interaction variable $d$ Constraint $\times d$ Block-owned pyramid $\times d$ PostCrisis, our measure of the post-crisis impact of the presence of financial constraints, is not significant for any of our three financial constraint variables; we conclude that pyramidal block ownership per se does not lead to a different adjustment in dividend payouts after the crisis, even for firms that show signs of financial distress.

To complete the discussion, the regressions in Table 3 (Panel A and B) confirm that dividend policy depends on other variables: unsurprisingly, firms with higher Tobin's Q and higher profitability (ROA) pay higher dividends, and firms with higher sales growth pay less dividends. We also confirm DeAngelo et al. (2006)'s finding that dividends increase for firms capable of financing equity from retained earnings rather than raised capital when including their suggested life cycle variable retained earnings/total equity. Dividend payouts do not depend on our measure of stock market liquidity (we report results using Banerjee et al. (2007)'s first liquidity measure of annual stock turnover), or other control variables included in the regression. Company leverage is not significant when we

\footnotetext{
${ }^{23}$ The regression include year and industry fixed effects, so the dummy $d$ PostCrisis as a primitive term would be redundant and hence is not included.
} 
control for post-crisis leverage (regressions (4) to (6)). Though not shown, the regressions in the two tables load the same on our industry categories.

\subsection{Pyramidal Debt and Dividend Payouts Before and After the Crisis}

We consider the impact of pyramidal debt on payout policies in Table 4, presenting our main result that companies relying heavily on pyramidal debt maintain substantial dividend payment levels after the crisis. We are particularly interested in the question whether the crisis, as measured by the dummy variable $d$ PostCrisis, had an impact on the relationship between pyramidal debt and dividend policy. Since we want to take a closer look at the financial structure of the holding companies in pyramids, this table limits the attention to pyramid-controlled operating firms, in contrast to Table 3 that looks at all firms. We show results for our two measures of pyramidal leverage, average leverage (regressions (1) to (3)) and equivalent leverage (regressions (4) to (6)). Table 4, Panel A, documents that pyramidal debt per se, whether measured by average or equivalent leverage, has no clearly significant effect for the dividend policy of the operating company. The coefficient is slightly negative, but essentially insignificant (with significance at the $10 \%$ level in only one out of six regressions). In these as in all following regressions, we assume that the leverage in holding entities for which we do not observe financial information is the same as for the observed entities of the same companies (see Table 7 for the robustness when altering this assumption).

Our identification exploits the fact that there should be a predictable heterogeneous response to the crisis shock according to the exposure to pyramidal leverage. While the shock affects all firms, the dividend response to the shock should be more mitigated for firms with blockholders exposed to pyramidal leverage. Our approach is a difference-in-difference estimation of this differential response to the crisis shock, measured by the interaction term between $d$ PostCrisis and our two measures of pyramidal leverage. The interaction term Pyramidal leverage $\times$ $d$ PostCrisis in Table 4, Panel A, is our main variable of interest.

We find a uniformly significant positive relationship between the interaction term Pyramidal leverage $x$ $d$ PostCrisis in Panel A of Table 4 and dividend policy in all specifications, with significance at the 5\% level in 3 out of 6 specifications, and at $10 \%$ in the 3 remaining equations. This is the main answer to our research question; it says that, in order for dominant owners to be able to service their private debts, companies with levered blockholders are willing to maintain dividends in reaction to the crisis. For the interpretation, it should be kept in mind that the financial crisis hit France with a delay. 
We also consider whether the post-crisis dividend adjustment is different for firms exposed to financial distress. In Table 4, Panel B, we report the results when we interact the variable of interest Pyramidal leverage $\times$ $d$ PostCrisis with our three variables of financial distress, Interest coverage ratio, Leverage ratio and Net debt/EBITDA. The triple interaction coefficient is negative as we would expect (meaning that firms more likely exposed to financial distress concerns are less likely to maintain pre-crisis levels of dividends) but it is significantly negative only for Net debt/EBITDA. Crucially, our main variable of interest Pyramidal leverage $\times d$ PostCrisis remains positive and significant, meaning that companies with leveraged blockholder cut their dividends by a significantly smaller amount compared with other firms even when we explicitly include financial distress.

As a robustness check, we repeat all regressions in Tables 3 and 4 with two-year lagged ownership measures instead of the one-year lagged ownership measures that we use in all regressions reported in these tables. The results (not reported in tables) are robust to this two-year lag. ${ }^{24}$ The stability of the ownership structure and these extended lags imply that endogeneity of this variable is not likely to induce biased estimates.

\section{Anatomy of Dividend Pass-Through in Pyramidal Structure}

For additional evidence on the transmission mechanism, we disaggregate and investigate information for the flow of funds within pyramids. We inspect directly the financial situation of each holding company, in particular its capital structure and dividends. We consider specifically the utilization of the dividends that each entity receives, and in particular focus on the fraction passed on to the next layer in the pyramidal chain. Following our hypothesis, we postulate that this fraction decreases in the entity's debt. Thus, the fraction of dividends that is ultimately passed on to the beneficial owner should decrease in the pyramidal debt exposure.

Specifically, we investigate the behavior and determinants of the dividend pass-through, the dividends ultimately received by the dominant shareholder as a fraction of the operating company's dividends made available to him. Formally, by dividend pass-through of the dominant owner, we refer to the fraction of the dividends that the operating company makes available to the dominant shareholder (through direct and indirect ownership links) that the dominant owner actually receives. Thus, this fraction excludes the part of dividends absorbed somewhere in the pyramidal chain.

Table 5 shows summary statistics for the holding companies of pyramid-controlled companies, encompassing all holding companies for which we observe financial information. We base our analysis on this sample (we present the statistics for the smaller subsample of holding entities and associated operating companies for

\footnotetext{
${ }^{24}$ In a few instances the significance of the results becomes weak; this is a consequence of the loss of power in our tests because we cannot use the first two years of our panel.
} 
which we have complete financial information on all holding entities in the pyramid in the Internet Appendix, Tables IA.3 and IA.4). Again, we show values for the pre-crisis and post-crisis period separately. Panel A presents the summary statistics for all holding companies with observable financial information. Total assets and the investment ratio (the fraction of the holding entity's assets that consists of its stake in the listed operating company) of the holding companies remain stable between the pre-crisis and post-crisis period, but debt and interest expenses rise whereas dividends received fall, measured as a fraction of total assets, albeit mostly not significantly, indicating the potential for heightened tension in the ability to service pyramidal debt. Indeed, the last two lines of Panel A show a precipitous fall in the mean coverage of interest obligations through dividend receipts: when we express dividends received as a fraction of the proportional debt service obligation of the holding entity (interest expense $\times$ investment ratio), we find that the fraction decreases by $43 \%$ from the pre-crisis to the post-crisis period in our preferred version where outliers are capped (investment ratio capped between 0 and 1, last line), and by $61 \%$ in the raw data. However, this coverage ratio remains at relatively comfortable median levels of 3 (mean above 30) even after the crisis. Thus, we expect tensions to be concentrated among companies at the top end of pyramidal debt.

Indeed, the picture changes when we split the sample to focus on companies with the highest pyramidal leverage exposure. In Panel B, we consider the top quartile of pyramidal holding companies by leverage (financial debt/total assets) separately from the rest of the sample. We find that the coverage ratio dividends received/(interest expense $\times$ investment ratio) is much lower for highly levered firms, at median levels between 1.28 and 1.56 before the crisis (mean levels above 5). This indicates a clear potential for tensions for the most levered blockholders. Remarkably, it remains stable or even increases (in the raw data) with the arrival of the crisis, in strong contrast to the rest of the sample of moderately levered pyramidal holding companies where the coverage ratio is much higher and falls with the crisis. We find similar differences when we split the sample by other measures of pyramidal leverage (not reported in tables).

Table 6 considers the determinants of dividend pass-through. Panel A presents summary statistics, separate for the pre-crisis years 2000-2008 and the post-crisis period starting in 2009. It shows that the mean (median) of the dividend pass-through in our sample is $59.6 \%(66.4 \%)$, i.e. ultimate owners receive on average less than $60 \%$ of the dividends made available to them. This proportion increases to $70.7 \%$ on average (median: $83.4 \%$ ) after the financial shock arrives, perhaps indicating that the ultimate owners have additional cash needs after the crisis that are not captured by the pyramidal debt in our sample, but the difference is not significant.

Panel B presents the regression results. The dependent variable is the dividend pass-through to the ultimate owner as a fraction of the dividends made available to him. Our variable of interest is the measure of pyramidal leverage (average leverage in regressions (1) and (3) and equivalent leverage in regressions (2) and (4)), either as a 
contemporaneous measure (regressions (1) and (2)) or as a lagged measure (regressions (3) and (4)). We focus on the number of pyramidal layers and one of our two pyramidal leverage measures. In the pre-crisis period, both measures of pyramidal leverage are significantly negative: a smaller fraction of dividends received is passed through to the ultimate owner if the pyramid is indebted (as a substantial part of dividends received by intermediate entities are used to service the debt). When we use lagged pyramidal leverage terms (in regressions (3) and (4)) to be more certain about the direction of causality, we find the same result.

To gauge the impact of the crisis shock, we consider the interaction terms of pyramidal debt with the dummy $d$ PostCrisis. Since Table 4 shows that dividends are increasing in pyramidal leverage, we expect that dividend policy may remain the same and hence the relationship between pass-through and pyramidal leverage may remain constant. Indeed, we find that the interacted terms are not significant, meaning that the adjustment does not come at the ultimate owner's expense; ultimate owners seem to be able to receive payouts that are uncorrelated with their pyramidal debt exposure.

Overall, our anatomy of the pass-through of dividends demonstrates that ultimate owners receive on average only $60 \%$ of the dividends that the operating company makes available to them, using the remainder mostly for debt service payments along the pyramidal chain. These relationships hold in normal times. The fact that the passthrough does not vary with pyramidal debt after the financial crisis shock appears to be consistent with our earlier results in Table 4: if companies do not cut their dividends because they cater to the needs for cash of the dominant owner's pyramidal leverage, then the use of those unchanged dividends in the pyramid should not change, either. This finding is also consistent with the hypothesis that pyramidal debt reinforces the pressure on operating companies to increases their payout ratios when hit by adverse shocks.

\section{Extensions and Robustness}

\subsection{Real Effects of Blockholder Leverage Under Duress}

When companies with levered owners increase dividends during times of financial duress, negative real effects such as a cut in investments could be the consequence. We investigate whether pyramidal debt has such a negative impact on investments. We look at the full sample, and we also look at the subsample of pyramid-controlled firm, where we focus on the impact of pyramidal leverage, before and after the financial crisis. We find that neither before nor after the crisis is there any significant change in investment that can be attributed to pyramidal leverage. We do not tabulate these results, but include representative regressions in the Internet Appendix (Table IA.1).

Also in untabulated regressions, we investigate the determinants of various measures of operational risk. We use the standard deviation of ROA, beta, and the standard deviation and semi-deviation of market return, all 
measured over a rolling 5-year window $(t-4$ to $t)$. While one of our four measures, the volatility of ROA, shows some association with pyramidal debt in the pre-crisis period, none of the four measures of operational risk shows any change as a function of pyramidal debt under the shock from the financial crisis. Our findings for investments and risk appear to be consistent: overall, pyramidal leverage is probably too conservative, and the effect leading to higher dividends too small to lead to a measurable reduction in investment or change in risk.

\subsection{Alternative Measures for Pyramidal Debt}

We have no capital structure information for $34.4 \%$ of the reported pyramidal holding companies, posing a challenge for the construction of our measures of pyramidal debt. We investigate the robustness of our results when using the most conservative assumption available for the capital structure of those holding entities with missing information. We now assume that, when calculating the values for the two measures of pyramidal debt, there is zero debt in a holding company in the pyramid when such data is not available, thereby presenting conservative estimates for our two leverage measures, average and equivalent. By contrast, in our main analysis, we assume that the leverage of those holding companies with missing capital structure observation corresponds to the average of the holding companies in the same pyramid when no such data is available.

Tables 7 and 8 present the result, reproducing our estimates of the dividend model (Table 4) and the dividend passthrough (Table 6). Importantly, the significance of the variables of interest, the interacted terms with the post-crisis dummy, and the explanatory power of the regressions are robust to this use of the most conservative measure of pyramidal leverage.

\subsection{Alternative Explanations for Dividend Levels in Pyramids}

Regarding alternative explanations, we consider first Almeida and Wolfenzon's (2006) theory stipulating that pyramids are used to create new businesses from retained earnings, thereby taking minority investors hostage in the interest of capital accumulation. Inspecting the asset base of holding companies, we find that on average the investment in the company one layer below comprises $60 \%$ of the total assets of the pyramidal entity (see Table 5 , Panel A). With the stake in the company below constituting over half of a typical holding company's assets, it is unlikely that French holding companies are predominantly used to accumulate new investments in other subsidiaries. Further evidence emerges when we analyze the relationship between dividends received and the uses for those dividends. If a holding company absorbs dividends, i.e. receives dividends but does not pass them on to the next layer, it will put them to one of three uses: (1) to pay debt service; (2) to make investments; and (3) to save by increasing cash or paying down debt. Performing correlation analyses with these three variables, we find that the 
correlation between dividends received and interest rate obligations is very high, at $\rho \geq 0.6$ for various variable definitions. This is in contrast to the absence of any correlation between dividends received and the two other possible dividend uses, the increase in total assets between year $t$ and year $t+1$ and the increase in cash.

Multivariate regressions show evidence consistent with this correlation. We recall that the coefficients for the two pyramidal debt measures are highly significant and negative in Table 6, Panel B, and that this relationship does not change after the crisis. By contrast, we find no evidence (in untabulated regressions) that dividends passed through are determined by a holding vehicle's value or a change in its total assets. In conclusion, our findings suggest that debt service considerations are the major determinant of payout decisions in the pyramid.

\subsection{Double Voting Rights and Share Repurchases}

Pyramidal leverage also has an impact on the disproportionality between voting and cash flow rights. In France, pyramids are the only available control-enhancing mechanism, besides double voting rights. One final possibility we explore is that owners might choose pyramidal leverage mostly as a means to magnify their effective control wedge.

To investigate this possibility, we explicitly analyze double voting rights, which are a widely used controlenhancing mechanism in France. ${ }^{25}$ According to French law, the company's charter can convey a double voting right to each share if the share is held for a specified period, which must be between 2 and 4 years. Thus, double voting rights are distinct from dual-class shares as they are a premium for loyalty that is non-exclusive (every share acquires the right after satisfying the holding requirement) and is lost when the share is sold. Controlling owners who adopt double voting rights are those most likely to be driven by control motives, and the use of pyramidal leverage will magnify the control wedge most for those owners.

To assess the role played by double voting rights, we trace the actual voting rights (including double voting rights) of the dominant owner in our 2003 sample from annual reports and disclosure statements obtained from the AMF, the French stock market regulator. We find that for operating firms, double voting rights make no difference to the control rights allocation - either because the dominant owner already holds more than $50 \%$ of the votes, or because the firm remains widely held after accounting for double voting rights. We calculate a modified measure for the control wedge taking into account double voting rights, and rerun our relevant regressions with this modified

\footnotetext{
25 Ginglinger and Hamon (2012) report that about two thirds of listed French companies adopt double voting rights and that they are most popular among smaller and family companies; our numbers are comparable. Two other control-enhancing devices are in principle available but rarely used: non-voting shares are used by less than $2 \%$ of blockholder-controlled firms; voting caps are used by only about 1\% (Ginglinger and Hamon, 2012). In 2014, the French law changed and the grant of double voting rights was made the legal default status, leading to a considerably increase of their use, even though companies could opt out (so-called Florange law, see Becht, Kamisarenka, Pajuste, 2018). This law change, however, occurred after our sample period.
} 
measure. Our results are unchanged by this modification (not reported in tables): the control wedge variable remains insignificant, whereas the variables for pyramidal leverage remain strongly significant.

We do not explicitly include stock repurchases in our study. Stock repurchases in France are relatively small in value: David and Ginglinger (2016) report a ratio of buybacks to dividends of about 1:5 for the 2003-2012 period for French companies, and report that the ratio is the same for firms that drastically cut dividends during the postcrisis period after 2008 and firms that do not. These proportions make it unlikely that including stock buybacks would alter our results. Also, David and Ginglinger (2016) find that stock repurchases in the 2003-2007 period are unrelated to firms' decision whether to drastically cut dividends during the post-crisis period. In addition, in a preliminary test of the early years of our sample period (years 2000-2003), we include data on actual stock repurchases and find that their inclusion does not alter our findings on dividend payouts in this subsample. For these reasons, we are confident that our main results would not be altered when adding the value of stock repurchases to our dependent variables.

\section{Conclusions}

We investigate the use of leverage by dominant owners by analyzing the case of France where blockholders have tax incentives to structure their leverage in holding vehicles, and holding companies are relatively transparent. We suggest that debt in pyramidal holdings increases the need for dividend payouts such that the controlling owner can meet the debt service obligations. These predictions are borne out in our empirical investigation around the 2008/2009 financial crisis. We find the use of debt in holding companies leads to increased dividend payouts during the crisis years. We use different metrics to aggregate the leverage of pyramids and find that in each case the dividend payouts of the listed holding company are largely determined by the debt service obligations in the holding companies.

We analyze the actual dividend payouts to dominant owners along the pyramidal chain. We find that on average, leveraged owners ultimately receive only about $60 \%$ of the dividends made available to them, with the rest being absorbed in pyramids mainly to service debt. Thus, while many leveraged blockholders probably have the capacity to service their pyramidal debt by reducing their dividend income, our results show that they prefer on average to pass on at least parts of the required adjustment to the companies they control via a change in the payout policy. 


\section{References}

Adams, R. and D. Ferreira, 2008, “One share, one vote: The empirical evidence,” Review of Finance 12, 51-91.

Agrawal, A. and C.R. Knoeber, 1996, "Firm performance and mechanisms to control agency problems between managers and shareholders," Journal of Financial and Quantitative Analysis 31, 377 - 397.

Allen, F., and R. Michaely, 2003, "Payout policy". Handbook of the Economics of Finance Handbook of the Economics of Finance, ed. by G. M. Constantinides, M.Harris, R.M. Stulz, Elsevier:North Holland, Vol. $1,337-429$.

Almeida, H. and D. Wolfenzon, 2006, "A theory of pyramidal ownership and family business groups," Journal of Finance 61, 2637-2680.

Almeida, H., S. Park, M. Subramahnyam, and D. Wolfenzon, 2011, "The Structure and Formation of Business Groups: Evidence from Korean Chaebols," Journal of Financial Economics 99, 447-475.

Banerjee, S., V.A. Gatchev, and P.A. Spindt, , 2007, "Stock market liquidity and firm dividend policy." Journal of Financial and Quantitative Analysis 42, 369-397.

Becht, M., Y. Kamisarenka, and A.Pajuste, 2018, "Loyalty Shares with Tenure Voting - Does the Default Rule Matter? Evidence from the Loi Florange Experiment." ECGI Working Paper 398/2018.

Bertrand, M., P. Mehta, and S. Mullainathan, 2002, "Ferreting out tunnelling: an application to Indian business groups," Quarterly Journal of Economics 117, 121-148.

Bianco, M. and G. Nicodano, 2006, “Pyramidal groups and debt,” European Economic Review 50, 937-61.

Bloch, L. and E. Kremp, 2001, "Ownership and voting power in France," in: The Control of Corporate Europe, F. Barca and M. Becht (Eds), Oxford Press, UK.

Brockman, P. and E. Unlu, , 2009, "Dividend policy, creditor rights, and the agency costs of debt," Journal of Financial Economics 92, 276-299.

Burkart, M. and S. Lee, 2008, "One share, one vote: The theory,” Review of Finance 12, 1-49.

Chapelle, A. and A. Szafarz, 2005, “Controlling firms through majority rule,” Physica 355, 509-529.

Claessens, S., S. Djankov, and L. Lang, 2000, "The separation of ownership and control in East Asian corporations," Journal of Financial Economics 58, 81-112.

Claessens, S., S. Djankov, J. Fan, and L. Lang, 2002, "Disentangling the incentive and entrenchment effects of large shareholdings", Journal of Finance 57, 2741-2771.

Cronqvist, H. and R. Fahlenbrach, 2009, "Large shareholders and corporate policies," Review of Financial Studies 22, 3941-3976.

Chu, Y., 2017, "Shareholder-creditor conflict and payout policy: Evidence from mergers between lenders and shareholders," The Review of Financial Studies 31, 3098-3121.

David, T. and E. Ginglinger, 2016, "When cutting dividends is not bad news: The case of optional stock dividends", Journal of Corporate Finance 40, 174-191.

DeAngelo, H. and L. DeAngelo, 1990, "Dividend Policy and Financial Distress: An Empirical Investigation of Troubled NYSE Firms," Journal of Finance 45, 1415-1431. 
DeAngelo, H., L. DeAngelo and R.M. Stulz, 2006, "Dividend policy and the earned/contributed capital mix: a test of the lifecycle theory," Journal of Financial economics 81, 227-254.

Demsetz, H. and K. Lehn, 1985, "The structure of corporate ownership: Causes and consequences," Journal of Political Economy 93, 1155-1177.

Dou, Ying, R.W. Masulis and J. Zein, 2019, "Shareholder Wealth Consequences of Insider Pledging of Company Stock as Collateral for Personal Loans,” ECGI Working Paper 592/2019.

Faccio, M. and L. Lang, 2002, "The ultimate ownership of Western European corporations," Journal of Financial Economics 65, 365-395.

Faccio, M., L. Lang, and L. Young, 2001, "Dividends and expropriation,” American Economic Review 91, 5478.

Financial Stability Board, 2015, Corporate Funding Structures and Incentives, Reports to the G20 2015/09, available at http://www.fsb.org/2015/09/corporate-funding-structures-and-incentives.

Gilje, E. P., 2016. "Do firms engage in risk-shifting? Empirical evidence," Review of Financial Studies 29, 2925-2954.

Ginglinger, E. and J. Hamon, 2012, “Ownership, control and market liquidity,” Finance 33, 61-99.

Gopalan, R., V.K. Nanda, and A. Seru, 2007, "Do business groups use dividends to fund investments?," Working paper, Washington University, http://ssrn.com/abstract=967328.

Hoshi, T., A. Kashyap and D. Scharfstein, 1990, "The role of banks in reducing the costs of financial distress in Japan,” Journal of Financial Economics 27, 67-88.

Imbens, G. and J. Angrist, 1994, "Identification and estimation of local average treatment effects," Econometrica $62,467-475$.

Jensen, M., 1986, "Agency costs of free cash flows, corporate finance and takeovers," American Economic Review 76, 323-329.

La Porta, R., F. Lopez-de-Silanes, and A. Shleifer, 1999, "Corporate ownership around the world," Journal of Finance 54, 471-517.

La Porta, R., F. Lopez-de-Silanes, A. Shleifer, and R.W. Vishny, 2000, “Agency problems and dividend policies around the world," Journal of Finance 55, 1-33.

Luciano, E. and G. Nicodano, 2014, "Guarantees, Leverage, and Taxes", Review of Financial Studies 27, 27362772.

Megginson, W. and H. Von Eije, 2008, "Dividends and share repurchases in the European Union," Journal of Financial Economics 91, 347-374.

Myers, S. C., 1977, “Determinants of Corporate Borrowing,” Journal of Financial Economics 5, 147-175.

Data Set: https://www.refinitiv.com/en/financial-data, https://www.dafsaliens.fr, and https://www.bvdinfo.com/en-gb/our-products/data/national/diane 


\section{Definition of Variables}

Dividend / Total assets

Dividend / Cash flows

$\operatorname{Ln}$ (Total assets)

Sales growth

Operational risk

Loss

Capex

Tobin's Q

Cash flow

ROA

Direct ownership

Control wedge

Interest coverage ratio

Leverage ratio

Net debt / EBITDA

Retained earnings/ Total equity

Annual share turnover

Widely held

Block owned pyramid

Block owned no pyramid

Investment ratio

Interest expense

Dividends received
Cash dividend divided by total assets, with dividend measured in year $t+1$.

Cash dividend divided by net income plus depreciation, with dividend measured at $t+1$; set to one when cash flows are negative or when the ratio exceeds one.

Natural logarithm of book of value total assets.

Two-year growth rate of sales.

Standard deviation of return on assets measured over five years ( $t-4$ to $t)$.

Dummy variable equal one when net income is negative and zero otherwise.

Capital expenditure.

Market capitalization divided by book value of assets.

Net income plus depreciation.

Return on assets.

Proportion of common shares held by the dominant owner (largest owner when controlling more than $20 \%$ of voting rights). See Section 3.2 for details.

Discrepancy between voting and cash flow rights. See Section 3.2 for details.

EBIT / Interest expense, similar to Hoshi et al. (1990).

Total financial debt over total assets.

Total financial debt minus cash and cash equivalents, as a fraction of EBITDA.

Aggregate of (cumulative) retained earnings as a proportion of total equity.

Annual volume / number of shares outstanding. Annual volume is the cumulative daily trading volume over the calendar year; number of shares the number of common shares outstanding at fiscal-year end.

Dummy variable equal to one if the company has no dominant owner, controlling more than $20 \%$ of voting rights.

Dummy variable equal to one if the company has a dominant owner, controlling more than $20 \%$ of voting rights, who controls the company using at least one holding vehicle.

Dummy variable equal to one if the company has a dominant owner, controlling more than $20 \%$ of voting rights, who does not make use of holding vehicles.

Part of all assets of a holding company that is constituted by the ultimate owners' equity stake in the pyramidal entity directly below, or in the listed operating company if the listed operating company is placed immediately below the holding entity (investment ratios are lagged by one period, and capped within the interval $[0,1])$.

Total of interest expenditure by a holding vehicle.

Amount of dividends received by the holding entity (in euros). 
Dividends received/Total assets

Div. received / (Interest expense

$\times$ Investment ratio)

Div. received / (Interest expense $\times$ Investment ratio capped

between 0 and 1)

Pyramidal leverage (average)

Pyramidal leverage (equivalent)

Number of layers

Proportion of missing entities

$d$ PostCrisis

$d$ Next is Ultimate Owner

DivPassThrough
Dividends received, divided by the total assets of the holding entity.

Dividends received, divided by Interest expense $\times$ Investment ratio.

Dividends received, divided by Interest expense $\times$ Investment ratio. The value of this ratio is fixed at zero if the calculation yields a negative value, and fixed at one if the calculation yields a value larger than one.

Mean leverage ratio of all observed pyramidal entities in the pyramidal structure. See Section 3.2 for details.

Aggregate leverage exposure of the ultimate owner through all pyramidal entities including the bottom company in the pyramidal structure. See Section 3.2 for details of its calculation.

Longest chain of companies linking the ultimate owner to the operating company, including the operating company, so the number of holding companies between ultimate owner and operating company is number of layers -1 .

Fraction of holding companies for which we do not observe the capital structure.

Dummy variable equal to one for the post-crisis year 2009, 2010, 2011.

Dummy variable equal to one if the owner of a holding vehicle controlling more than $20 \%$ of its voting rights is the ultimate dominant owner of the operating company.

Fraction of the dividends that the operating company makes available to the dominant owner that is eventually received by the dominant owner, i.e. dividends received by the dominant owner / (dominant owner's combined ownership in the operating company $x$ dividend paid by operating company). 
Table 1: Summary statistics operating companies

\begin{tabular}{|c|c|c|c|c|c|c|c|c|c|c|c|}
\hline & & & \multicolumn{3}{|c|}{ Pre-crisis period (2000-2008) } & \multicolumn{4}{|c|}{ Post-crisis period (2009-2011) } & \multirow{2}{*}{$\begin{array}{c}\text { Period } \\
\text { 2012-2014 } \\
\text { Full } \\
\text { sample }\end{array}$} & \multirow{2}{*}{ 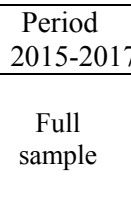 } \\
\hline & & $\begin{array}{c}\text { Full } \\
\text { sample }\end{array}$ & $\begin{array}{c}\text { Widely } \\
\text { held }\end{array}$ & $\begin{array}{c}\text { Block } \\
\text { owned } \\
\text { pyramids }\end{array}$ & $\begin{array}{c}\text { Block } \\
\text { owned, no } \\
\text { pyramids }\end{array}$ & $\begin{array}{c}\text { Full } \\
\text { sample }\end{array}$ & $\begin{array}{c}\text { Widely } \\
\text { held }\end{array}$ & $\begin{array}{c}\text { Block } \\
\text { owned } \\
\text { pyramids }\end{array}$ & $\begin{array}{c}\text { Block } \\
\text { owned, no } \\
\text { pyramids }\end{array}$ & & \\
\hline \multicolumn{12}{|l|}{ Financials } \\
\hline \multirow[t]{2}{*}{ Dividend / Total assets } & mean & 0.016 & 0.015 & 0.018 & 0.014 & 0.014 & 0.017 & 0.014 & 0.011 & 0.017 & 0.016 \\
\hline & median & 0.010 & 0.011 & 0.010 & 0.009 & 0.008 & 0.010 & 0.008 & 0.007 & 0.010 & 0.010 \\
\hline \multirow[t]{2}{*}{ Dividend / Cash flows } & mean & 0.179 & 0.188 & 0.194 & 0.147 & 0.193 & 0.209 & 0.198 & 0.161 & 0.226 & 0.198 \\
\hline & median & 0.129 & 0.138 & 0.136 & 0.110 & 0.126 & 0.159 & 0.123 & 0.106 & 0.149 & 0.147 \\
\hline \multirow[t]{2}{*}{$\operatorname{Ln}$ (Total assets) } & mean & 6.045 & 6.623 & 6.113 & 5.429 & 6.513 & 6.791 & 6.766 & 5.633 & 6.633 & 6.852 \\
\hline & median & 5.866 & 6.598 & 5.975 & 5.145 & 6.560 & 6.796 & 6.784 & 5.407 & 6.646 & 6.847 \\
\hline \multirow[t]{2}{*}{ Sales growth } & mean & 0.144 & 0.162 & 0.116 & 0.170 & 0.020 & 0.030 & 0.004 & 0.035 & 0.112 & 0.025 \\
\hline & median & 0.126 & 0.133 & 0.105 & 0.140 & 0.025 & 0.036 & 0.023 & 0.021 & 0.092 & 0.035 \\
\hline \multirow[t]{2}{*}{ Operational risk } & mean & 0.039 & 0.045 & 0.034 & 0.040 & 0.043 & 0.044 & 0.037 & 0.052 & 0.036 & 0.030 \\
\hline & median & 0.022 & 0.023 & 0.021 & 0.022 & 0.024 & 0.026 & 0.023 & 0.023 & 0.022 & 0.016 \\
\hline \multirow[t]{2}{*}{ Loss } & mean & 0.151 & 0.197 & 0.129 & 0.144 & 0.247 & 0.260 & 0.240 & 0.241 & 0.150 & 0.142 \\
\hline & median & - & - & - & - & - & - & - & - & - & - \\
\hline \multirow[t]{2}{*}{ Capex } & mean & 0.311 & 0.333 & 0.291 & 0.325 & 0.252 & 0.276 & 0.239 & 0.239 & 0.239 & 0.256 \\
\hline & median & 0.274 & 0.290 & 0.262 & 0.282 & 0.211 & 0.246 & 0.193 & 0.205 & 0.197 & 0.218 \\
\hline \multirow[t]{2}{*}{ Tobin's Q } & mean & 1.503 & 1.651 & 1.447 & 1.458 & 1.219 & 1.268 & 1.133 & 1.297 & 1.222 & 1.318 \\
\hline & median & 1.234 & 1.332 & 1.183 & 1.235 & 1.045 & 1.084 & 1.023 & 1.040 & 1.040 & 1.141 \\
\hline \multirow[t]{2}{*}{ Cash flow } & mean & 0.078 & 0.075 & 0.079 & 0.077 & 0.058 & 0.055 & 0.058 & 0.063 & 0.072 & 0.067 \\
\hline & median & 0.076 & 0.076 & 0.074 & 0.081 & 0.059 & 0.065 & 0.053 & 0.061 & 0.064 & 0.063 \\
\hline \multirow[t]{2}{*}{$\mathrm{ROA}$} & mean & 0.047 & 0.046 & 0.050 & 0.044 & 0.035 & 0.032 & 0.033 & 0.041 & 0.043 & 0.040 \\
\hline & median & 0.046 & 0.045 & 0.046 & 0.047 & 0.038 & 0.039 & 0.037 & 0.039 & 0.039 & 0.038 \\
\hline \multirow[t]{2}{*}{ Direct ownership } & mean & 0.432 & - & 0.375 & 0.521 & 0.439 & - & 0.391 & 0.526 & & \\
\hline & median & 0.399 & - & 0.328 & 0.510 & 0.399 & - & 0.341 & 0.531 & & \\
\hline \multirow[t]{2}{*}{ Control wedge } & mean & 1.764 & - & 2.070 & 1.291 & 1.977 & - & 2.337 & 1.327 & & \\
\hline & median & 1.470 & - & 1.667 & 1.006 & 1.431 & - & 1.628 & 1.185 & & \\
\hline \multicolumn{12}{|c|}{ Financial constraints, stock market liquidity, firm life cycle } \\
\hline \multirow[t]{2}{*}{ Interest coverage ratio } & mean & 24.374 & 16.916 & 26.074 & 28.398 & 27.453 & 21.748 & 25.497 & 39.854 & 27.511 & 31.566 \\
\hline & median & 5.459 & 5.850 & 4.702 & 6.261 & 5.018 & 4.879 & 4.656 & 6.107 & 6.215 & 7.659 \\
\hline \multirow[t]{2}{*}{ Leverage ratio } & mean & 0.228 & 0.227 & 0.243 & 0.208 & 0.246 & 0.244 & 0.260 & 0.225 & 0.223 & 0.216 \\
\hline & median & 0.216 & 0.207 & 0.234 & 0.197 & 0.228 & 0.216 & 0.243 & 0.216 & 0.205 & 0.205 \\
\hline \multirow[t]{2}{*}{ Net debt / EBITDA } & mean & 1.999 & 2.130 & 2.129 & 1.675 & 2.358 & 2.354 & 2.696 & 1.750 & 2.313 & 2.081 \\
\hline & median & 1.096 & 0.942 & 1.316 & 0.982 & 1.250 & 0.782 & 1.586 & 0.890 & 1.069 & 1.060 \\
\hline Retained earnings/ & mean & 0.463 & 0.339 & 0.515 & 0.492 & 0.482 & 0.373 & 0.565 & 0.500 & 0.541 & 0.551 \\
\hline Total equity & median & 0.562 & 0.459 & 0.610 & 0.604 & 0.640 & 0.534 & 0.677 & 0.699 & 0.676 & 0.678 \\
\hline
\end{tabular}


Table 1: Summary statistics (continued)

\begin{tabular}{|c|c|c|c|c|c|c|c|c|c|c|c|}
\hline & & \multicolumn{4}{|c|}{ Pre-crisis period (2000-2008) } & \multicolumn{3}{|c|}{ Post-crisis period (2009-2011) } & \multicolumn{2}{|c|}{$2012-2014$} & \multirow{2}{*}{$\begin{array}{r}\text { 2015-2017 } \\
\begin{array}{c}\text { Full } \\
\text { sample }\end{array}\end{array}$} \\
\hline & & $\begin{array}{c}\text { Full } \\
\text { sample }\end{array}$ & $\begin{array}{l}\text { Widely } \\
\text { held }\end{array}$ & $\begin{array}{l}\text { Block } \\
\text { owned } \\
\text { pyramids }\end{array}$ & $\begin{array}{c}\text { Block } \\
\text { owned, no } \\
\text { pyramids }\end{array}$ & $\begin{array}{c}\text { Full } \\
\text { sample }\end{array}$ & $\begin{array}{l}\text { Widely } \\
\text { held }\end{array}$ & $\begin{array}{l}\text { Block } \\
\text { owned } \\
\text { pyramids }\end{array}$ & $\begin{array}{c}\text { Block } \\
\text { owned, no } \\
\text { pyramids }\end{array}$ & $\begin{array}{c}\text { Full } \\
\text { sample }\end{array}$ & \\
\hline \multirow[t]{2}{*}{ Annual share turnover } & mean & 0.332 & 0.559 & 0.219 & 0.307 & 0.431 & 0.640 & 0.288 & 0.376 & 0.368 & 0.317 \\
\hline & median & 0.111 & 0.271 & 0.086 & 0.083 & 0.166 & 0.348 & 0.095 & 0.125 & 0.148 & 0.147 \\
\hline \multicolumn{12}{|l|}{ Ownership structure } \\
\hline $\begin{array}{l}\text { Type of control } \\
\text { (percent of companies) }\end{array}$ & & 1.000 & 0.261 & 0.449 & 0.290 & 1.000 & 0.354 & 0.415 & 0.230 & & \\
\hline \multicolumn{12}{|l|}{ Dominant owner } \\
\hline Company & & 0.172 & - & 0.169 & 0.175 & 0.219 & - & 0.157 & 0.331 & & \\
\hline Family & & 0.225 & - & 0.266 & 0.161 & 0.204 & - & 0.237 & 0.145 & & \\
\hline Individual & & 0.256 & - & 0.278 & 0.222 & 0.288 & - & 0.343 & 0.187 & & \\
\hline State \& others & & 0.348 & - & 0.287 & 0.442 & 0.290 & - & 0.263 & 0.337 & & \\
\hline \multicolumn{12}{|l|}{ Industry sector } \\
\hline Energy \& materials & & 0.088 & 0.092 & 0.076 & 0.100 & 0.088 & 0.075 & 0.087 & 0.108 & & \\
\hline Industrials & & 0.208 & 0.210 & 0.189 & 0.238 & 0.208 & 0.220 & 0.200 & 0.205 & & \\
\hline Consumer discretionary & & 0.213 & 0.144 & 0.222 & 0.260 & 0.213 & 0.157 & 0.240 & 0.247 & & \\
\hline Consumer staples & & 0.113 & 0.099 & 0.133 & 0.093 & 0.113 & 0.071 & 0.130 & 0.145 & & \\
\hline IT \& Telecom & & 0.125 & 0.171 & 0.091 & 0.137 & 0.125 & 0.161 & 0.083 & 0.145 & & \\
\hline Others & & 0.254 & 0.284 & 0.290 & 0.172 & 0.254 & 0.315 & 0.260 & 0.151 & & \\
\hline \# observations & & 2160 & 563 & 970 & 627 & 720 & 254 & 300 & 166 & 720 & 720 \\
\hline
\end{tabular}

This table presents the summary statistics of the full sample and the three subsamples according to type of control (widelyheld firms, block-owned firms without pyramidal structures and block-owned firms with pyramidal structures), for the years 2000-2011. Presented are the mean and for continuous variables the median (in the row below).

The Financials are defined as follows. Dividend/total assets is defined as cash dividend over total assets. Dividends/cash flow is defined as cash dividend divided by net income plus depreciation. For both dividend measures the ratio is set to one when cash flows or earnings are negative and when the ratio exceeds one. The dividend variables are measured at $t+1$. Total assets is book value of total assets. Sales growth is the two-year growth rate of sales. Operational risk is the standard deviation of return on assets measured over five years $(t-4$ to $t)$. The dummy variable Loss equals one when net income is negative and zero otherwise. Capex is capital expenditure, Tobin's Q is market capitalization divided by book value of assets, ROA is return on assets. Direct ownership is the proportion of common shares held by the dominant owner. The control wedge is the discrepancy between voting and cash flow rights, as described in Section 3.2.

The measures for Financial constraints, stock market liquidity, firm life cycle are defined as follows. Interest coverage ratio = EBIT / Interest expense, similar to Hoshi et al. (1990). The leverage ratio is total (financial) debt over total assets, similar to $\mathrm{Chu}$ (2017). Annual share turnover = Annual volume / number of shares outstanding, where annual volume represents the cumulative daily trading volume over the calendar year and number of shares outstanding the number of common shares outstanding at fiscal-year end. Retained earnings/total equity is the aggregate of (cumulative) retained earnings as a proportion of total equity, similar to DeAngelo et al. (2006).

The variables in the categories Ownership structure, Dominant owner, and Industry sector are all dummy variables. The variable for dominant owner equals one if the dominant owner is respectively, an individual or family, another firm or the state. Six dummy variables describe the industry of the firm's main activities. 
Table 2: Summary statistics of pyramid-controlled companies in the pre-crisis (2000-2008) vs. post-crisis (2009-2011) years

\begin{tabular}{|c|c|c|c|c|c|c|c|c|c|c|c|}
\hline & \multicolumn{4}{|c|}{ Pre-crisis period (2000-2008) } & \multicolumn{4}{|c|}{ Post-crisis period (2009-2011) } & \multicolumn{3}{|c|}{ Test Pre-crisis vs. Post-crisis } \\
\hline & Mean & Median & Stdev & \# obs. & Mean & Median & Stdev & \#obs. & $t$-test & $\begin{array}{c}\text { sign rank } \\
\text { test }\end{array}$ & \# obs \\
\hline \multicolumn{12}{|l|}{ Financials } \\
\hline Dividend / Total assets & 0.018 & 0.010 & 0.035 & 969 & 0.014 & 0.008 & 0.020 & 299 & 0.055 & 0.860 & 240 \\
\hline Dividend / Cash flows & 0.194 & 0.136 & 0.224 & 929 & 0.198 & 0.123 & 0.260 & 285 & 0.417 & 0.032 & 240 \\
\hline Operational risk & 0.034 & 0.021 & 0.038 & 970 & 0.037 & 0.023 & 0.042 & 300 & 0.253 & 0.189 & 240 \\
\hline Loss & 0.129 & - & 0.335 & 970 & 0.240 & - & 0.428 & 300 & 0.000 & 0.000 & 240 \\
\hline Capex & 0.291 & 0.262 & 0.251 & 852 & 0.239 & 0.193 & 0.239 & 273 & 0.000 & 0.000 & 240 \\
\hline Tobin's Q & 1.447 & 1.183 & 0.902 & 965 & 1.133 & 1.023 & 0.367 & 300 & 0.000 & 0.000 & 240 \\
\hline Cash flow & 0.079 & 0.074 & 0.094 & 970 & 0.058 & 0.053 & 0.074 & 300 & 0.000 & 0.000 & 240 \\
\hline Number of layers & 2.640 & 2.000 & 1.446 & 970 & 2.827 & 2.000 & 1.620 & 300 & 0.024 & 0.262 & 240 \\
\hline Proportion of missing entities & 0.359 & - & 0.437 & 970 & 0.295 & - & 0.413 & 300 & 0.041 & 0.413 & 240 \\
\hline \multicolumn{12}{|c|}{ Financial constraints, stock market liquidity, firm life cycle } \\
\hline Interest Coverage Ratio & 26.074 & 4.702 & 88.707 & 890 & 25.497 & 4.656 & 90.414 & 282 & 0.262 & 0.601 & 240 \\
\hline Net debt / EBITDA & 2.129 & 1.316 & 2.854 & 874 & 2.696 & 1.586 & 3.569 & 258 & 0.002 & 0.000 & 240 \\
\hline Leverage ratio & 0.243 & 0.234 & 0.176 & 970 & 0.260 & 0.243 & 0.181 & 300 & 0.024 & 0.052 & 240 \\
\hline Annual share turnover & 0.219 & 0.086 & 0.383 & 970 & 0.288 & 0.095 & 0.437 & 299 & 0.000 & 0.002 & 240 \\
\hline Retained earnings / Total equity & 0.515 & 0.610 & 0.403 & 930 & 0.565 & 0.677 & 0.397 & 284 & 0.674 & 0.000 & 240 \\
\hline
\end{tabular}

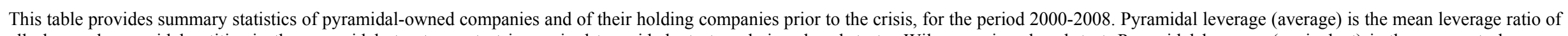

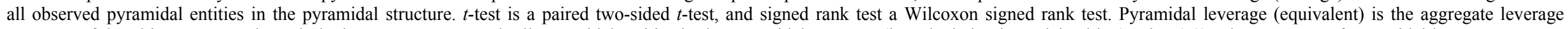

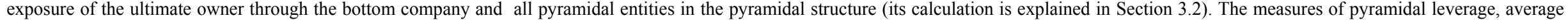

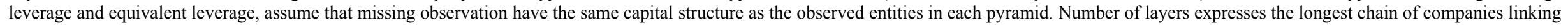

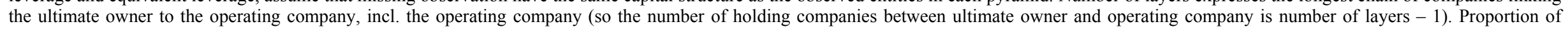

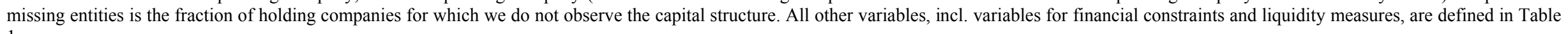
1. 
Table 3 : Determinants of dividend payouts for all firms, 2000-2011

Panel A: Baseline regressions

\begin{tabular}{|c|c|c|c|c|c|c|}
\hline Variables & $\begin{array}{c}(1) \\
\text { Div / TA }\end{array}$ & $\begin{array}{c}(2) \\
\operatorname{Div} / \mathrm{TA} \\
\end{array}$ & $\begin{array}{c}(3) \\
\text { Div / TA }\end{array}$ & $\begin{array}{c}(4) \\
\text { Div / TA }\end{array}$ & $\begin{array}{c}(5) \\
\text { Div / TA } \\
\end{array}$ & $\begin{array}{c}(6) \\
\text { Div / TA }\end{array}$ \\
\hline$d$ Block-owned pyramid & $\begin{array}{r}-0.00152 \\
(0.00308)\end{array}$ & $\begin{array}{r}-0.00178 \\
(0.00326)\end{array}$ & $\begin{array}{r}-0.00200 \\
(0.00318)\end{array}$ & $\begin{array}{r}-0.00152 \\
(0.00307)\end{array}$ & $\begin{array}{r}-0.00178 \\
(0.00325)\end{array}$ & $\begin{array}{r}-0.00200 \\
(0.00317)\end{array}$ \\
\hline$d$ Block-owned non-pyramid & $\begin{array}{r}-0.00552 * * \\
(0.00272)\end{array}$ & $\begin{array}{r}-0.00549 * * \\
(0.00273)\end{array}$ & $\begin{array}{r}-0.00586^{* *} \\
(0.00274)\end{array}$ & $\begin{array}{r}-0.00542 * * \\
(0.00267)\end{array}$ & $\begin{array}{r}-0.00539 * * \\
(0.00267)\end{array}$ & $\begin{array}{r}-0.00575 * * \\
(0.00268)\end{array}$ \\
\hline $\begin{array}{l}d \text { Block-owned pyramid } \times \\
d \text { PostCrisis }\end{array}$ & $\begin{array}{r}0.00571 \\
(0.00352)\end{array}$ & $\begin{array}{r}0.00008 \\
(0.00340)\end{array}$ & $\begin{array}{r}0.00037 \\
(0.00344)\end{array}$ & $\begin{array}{r}0.00069 \\
(0.00357)\end{array}$ & $\begin{array}{r}0.00024 \\
(0.00351)\end{array}$ & $\begin{array}{r}0.00053 \\
(0.00353)\end{array}$ \\
\hline $\begin{array}{l}d \text { Block-owned non-pyramid } \times \\
d \text { PostCrisis }\end{array}$ & $\begin{array}{r}0.00158 \\
(0.00309)\end{array}$ & $\begin{array}{r}0.00119 \\
(0.00294)\end{array}$ & $\begin{array}{r}0.00146 \\
(0.00302)\end{array}$ & $\begin{array}{r}0.00132 \\
(0.00300)\end{array}$ & $\begin{array}{r}0.000957 \\
(0.00285)\end{array}$ & $\begin{array}{r}0.00118 \\
(0.00293)\end{array}$ \\
\hline Leverage & $\begin{array}{c}-0.0204 * * \\
(0.00891)\end{array}$ & $\begin{array}{r}-0.0204 * * \\
(0.0101)\end{array}$ & $\begin{array}{r}-0.0197 * * \\
(0.00999)\end{array}$ & $\begin{array}{l}-0.0179 \\
(0.0109)\end{array}$ & $\begin{array}{r}-0.0181 \\
(0.0120)\end{array}$ & $\begin{array}{r}-0.0172 \\
(0.0119)\end{array}$ \\
\hline Leverage $\times d$ PostCrisis & & & & $\begin{array}{r}-0.00955 \\
(0.0101)\end{array}$ & $\begin{array}{r}-0.00902 \\
(0.0107)\end{array}$ & $\begin{array}{r}-0.00994 \\
(0.0108)\end{array}$ \\
\hline $\operatorname{Ln}$ (Total assets) & $\begin{array}{r}-0.00001 \\
(0.00050)\end{array}$ & $\begin{array}{r}0.00002 \\
(0.00050)\end{array}$ & $\begin{array}{r}-0.00007 \\
(0.00052)\end{array}$ & $\begin{array}{r}-0.00007 \\
(0.00049)\end{array}$ & $\begin{array}{r}-0.00003 \\
(0.00049)\end{array}$ & $\begin{array}{l}--0.00005 \\
(0.00051)\end{array}$ \\
\hline Cash and equivalents & $\begin{array}{r}0.00343 \\
(0.00738)\end{array}$ & $\begin{array}{r}0.00243 \\
(0.00718)\end{array}$ & $\begin{array}{r}0.00233 \\
(0.00713)\end{array}$ & $\begin{array}{r}0.00339 \\
(0.00738)\end{array}$ & $\begin{array}{r}0.00238 \\
(0.00717)\end{array}$ & $\begin{array}{r}0.00227 \\
(0.00713)\end{array}$ \\
\hline$d$ Loss & $\begin{array}{r}0.00327 \\
(0.00387)\end{array}$ & $\begin{array}{r}0.00456 \\
(0.00441)\end{array}$ & $\begin{array}{r}0.00544 \\
(0.00459)\end{array}$ & $\begin{array}{r}0.00349 \\
(0.00376)\end{array}$ & $\begin{array}{r}0.00477 \\
(0.00429)\end{array}$ & $\begin{array}{r}0.00567 \\
(0.00448)\end{array}$ \\
\hline Operating risk & $\begin{array}{r}0.00126 \\
(0.0254)\end{array}$ & $\begin{array}{r}0.0151 \\
(0.0305)\end{array}$ & $\begin{array}{r}0.0217 \\
(0.0321)\end{array}$ & $\begin{array}{r}0.00229 \\
(0.0256)\end{array}$ & $\begin{array}{r}0.0162 \\
(0.0308)\end{array}$ & $\begin{array}{r}0.0230 \\
(0.0324)\end{array}$ \\
\hline Sales growth & $\begin{array}{r}-0.00946 * * \\
(0.00473)\end{array}$ & $\begin{array}{c}-0.0101 * * \\
(0.00493)\end{array}$ & $\begin{array}{r}-0.00974 * \\
(0.00498)\end{array}$ & $\begin{array}{r}-0.00948 * * \\
(0.00472)\end{array}$ & $\begin{array}{c}-0.0101 * * \\
(0.00490)\end{array}$ & $\begin{array}{r}-0.00971^{*} \\
(0.00495)\end{array}$ \\
\hline Tobin's Q & $\begin{array}{r}0.00965 * * * \\
(0.00338)\end{array}$ & $\begin{array}{r}0.00868 * * * \\
(0.00320)\end{array}$ & $\begin{array}{r}0.00841 * * * \\
(0.00316)\end{array}$ & $\begin{array}{r}0.00969 * * * \\
(0.00340)\end{array}$ & $\begin{array}{r}0.00872 * * * \\
(0.00322)\end{array}$ & $\begin{array}{r}0.00844 * * * \\
(0.00318)\end{array}$ \\
\hline ROA & $\begin{array}{r}0.0948 * * * \\
(0.0345)\end{array}$ & $\begin{array}{l}0.104 * * \\
(0.0442)\end{array}$ & $\begin{array}{l}0.113 * * \\
(0.0463)\end{array}$ & $\begin{array}{r}0.0951 * * * \\
(0.0344)\end{array}$ & $\begin{array}{l}0.104 * * \\
(0.0443)\end{array}$ & $\begin{array}{l}0.113 * * \\
(0.0464)\end{array}$ \\
\hline Annual share turnover & $\begin{array}{r}-0.00005 \\
(0.000965)\end{array}$ & & $\begin{array}{r}0.00096 \\
(0.00098)\end{array}$ & $\begin{array}{r}-0.00006 \\
(0.00096)\end{array}$ & & $\begin{array}{r}0.00095 \\
(0.00097)\end{array}$ \\
\hline Retained earnings / Total equity & & $\begin{array}{r}0.00448 * * * \\
(0.00147)\end{array}$ & $\begin{array}{r}0.00467 * * * \\
\quad(0.00151)\end{array}$ & & $\begin{array}{r}0.00454 * * * \\
(0.00149)\end{array}$ & $\begin{array}{r}0.00473 * * * \\
(0.00154)\end{array}$ \\
\hline Year and industry FE & $\mathrm{Y}$ & Y & $\mathrm{Y}$ & $\mathrm{Y}$ & $\mathrm{Y}$ & $\mathrm{Y}$ \\
\hline $\begin{array}{l}\text { Observations } \\
\text { R-squared }\end{array}$ & $\begin{array}{l}2,620 \\
0.244 \\
\end{array}$ & $\begin{array}{l}2,543 \\
0.241\end{array}$ & $\begin{array}{l}2,523 \\
0.247\end{array}$ & $\begin{array}{l}2,620 \\
0.245\end{array}$ & $\begin{array}{l}2,543 \\
0.241\end{array}$ & $\begin{array}{l}2,523 \\
0.247\end{array}$ \\
\hline
\end{tabular}


(Table 3 continued) Panel B: Interaction with financial constraints variables in post-crisis period

\begin{tabular}{|c|c|c|c|c|c|c|}
\hline \multirow[t]{2}{*}{$\begin{array}{l}\text { Variables } \\
\text { Measure of Financial Constraint }\end{array}$} & $\begin{array}{c}(1) \\
\text { Div / TA }\end{array}$ & $\begin{array}{c}\text { (2) } \\
\text { Div / TA }\end{array}$ & $\begin{array}{c}\text { (3) } \\
\text { Div / TA }\end{array}$ & $\begin{array}{c}(4) \\
\text { Div / TA }\end{array}$ & $\begin{array}{c}\text { (5) } \\
\text { Div / TA }\end{array}$ & $\begin{array}{c}(6) \\
\text { Div / TA }\end{array}$ \\
\hline & \multicolumn{2}{|c|}{ Interest Coverage Ratio } & \multicolumn{2}{|c|}{ Net Debt/EBITDA } & \multicolumn{2}{|c|}{ Leverage Ratio } \\
\hline$d$ Block-owned pyramid & $\begin{array}{l}-0.00212 \\
(0.00275)\end{array}$ & $\begin{array}{l}-0.00207 \\
(0.00275)\end{array}$ & $\begin{array}{l}-0.00262 \\
(0.00295)\end{array}$ & $\begin{array}{l}-0.00261 \\
(0.00295)\end{array}$ & $\begin{array}{l}-0.00240 \\
(0.00286)\end{array}$ & $\begin{array}{l}-0.00238 \\
(0.00286)\end{array}$ \\
\hline$d$ Block-owned non-pyramid & $\begin{array}{l}-0.00435 \\
(0.00265)\end{array}$ & $\begin{array}{l}-0.00429 \\
(0.00265)\end{array}$ & $\begin{array}{l}-0.00646^{* *} \\
(0.00280)\end{array}$ & $\begin{array}{c}-0.00646^{* *} \\
(0.00280)\end{array}$ & $\begin{array}{c}-0.00619 * * \\
(0.00262)\end{array}$ & $\begin{array}{c}-0.00618 * * \\
(0.00263)\end{array}$ \\
\hline $\begin{array}{l}d \text { Block-owned pyramid } \times \\
d \text { PostCrisis }\end{array}$ & $\begin{array}{c}0.00215 \\
(0.00320)\end{array}$ & $\begin{array}{c}0.00129 \\
(0.00344)\end{array}$ & $\begin{array}{c}0.00256 \\
(0.00367)\end{array}$ & $\begin{array}{c}0.00228 \\
(0.00401)\end{array}$ & $\begin{array}{l}-0.000165 \\
(0.00337)\end{array}$ & $\begin{array}{l}0.000636 \\
(0.00362)\end{array}$ \\
\hline $\begin{array}{l}d \text { Block-owned non-pyramid } \times \\
d \text { PostCrisis }\end{array}$ & $\begin{array}{r}-0.000374 \\
(0.00273)\end{array}$ & $\begin{array}{l}-0.00119 \\
(0.00279)\end{array}$ & $\begin{array}{l}0.000741 \\
(0.00305)\end{array}$ & $\begin{array}{l}0.000489 \\
(0.00297)\end{array}$ & $\begin{array}{c}0.00131 \\
(0.00288)\end{array}$ & $\begin{array}{c}0.00210 \\
(0.00293)\end{array}$ \\
\hline Leverage & $\begin{array}{l}-0.0107 \\
(0.0120)\end{array}$ & $\begin{array}{l}-0.0105 \\
(0.0120)\end{array}$ & $\begin{array}{l}-0.0260 \\
(0.0161)\end{array}$ & $\begin{array}{l}-0.0262 \\
(0.0160)\end{array}$ & $\begin{array}{l}-0.0197 \\
(0.0168)\end{array}$ & $\begin{array}{l}-0.0199 \\
(0.0169)\end{array}$ \\
\hline Leverage $\times d$ PostCrisis & $\begin{array}{l}-0.00252 \\
(0.0115)\end{array}$ & $\begin{array}{l}0.00243 \\
(0.0132)\end{array}$ & $\begin{array}{l}-0.00930 \\
(0.0153)\end{array}$ & $\begin{array}{c}-0.00684 \\
(0.0190)\end{array}$ & $\begin{array}{l}-0.0115 \\
(0.0149)\end{array}$ & $\begin{array}{l}-0.0211 \\
(0.0185)\end{array}$ \\
\hline$d$ Loss & $\begin{array}{c}0.00198 \\
(0.00354)\end{array}$ & $\begin{array}{c}0.00237 \\
(0.00359)\end{array}$ & $\begin{array}{c}0.00357 \\
(0.00381)\end{array}$ & $\begin{array}{c}0.00361 \\
(0.00380)\end{array}$ & $\begin{array}{c}0.00560 \\
(0.00443)\end{array}$ & $\begin{array}{c}0.00555 \\
(0.00443)\end{array}$ \\
\hline Annual share turnover & $\begin{array}{c}0.000901 \\
(0.000954)\end{array}$ & $\begin{array}{c}0.000860 \\
(0.000955)\end{array}$ & $\begin{array}{l}0.00188^{*} \\
(0.00105)\end{array}$ & $\begin{array}{l}0.00187 * \\
(0.00106)\end{array}$ & $\begin{array}{c}0.000922 \\
(0.000993)\end{array}$ & $\begin{array}{c}0.00102 \\
(0.00101)\end{array}$ \\
\hline Retained earnings / Total equity & $\begin{array}{c}0.00453 * * * \\
(0.00128)\end{array}$ & $\begin{array}{c}0.00448 * * * \\
(0.00129)\end{array}$ & $\begin{array}{c}0.00455^{* *} \\
(0.00177)\end{array}$ & $\begin{array}{c}0.00456 * * \\
(0.00176)\end{array}$ & & \\
\hline Financial Constraint & $\begin{array}{c}0.00004 \\
(0.00003)\end{array}$ & $\begin{array}{c}0.00004 \\
(0.00003)\end{array}$ & $\begin{array}{c}0.000995 * * * \\
(0.000380)\end{array}$ & $\begin{array}{c}0.00101 * * * \\
(0.000382)\end{array}$ & $\begin{array}{l}0.0048 * * * \\
(0.00152)\end{array}$ & $\begin{array}{c}0.0048 * * * \\
(0.00152)\end{array}$ \\
\hline $\begin{array}{l}d \text { Constraint } \times d \text { Block-owned } \\
\text { pyramid }\end{array}$ & $\begin{array}{l}-0.000697 \\
(0.00187)\end{array}$ & $\begin{array}{l}-0.000871 \\
(0.00189)\end{array}$ & $\begin{array}{c}0.00129 \\
(0.00348)\end{array}$ & $\begin{array}{c}0.00125 \\
(0.00350)\end{array}$ & $\begin{array}{c}0.00153 \\
(0.00402)\end{array}$ & $\begin{array}{c}0.00156 \\
(0.00403)\end{array}$ \\
\hline $\begin{array}{l}d \text { Constraint } \times d \text { Block-owned } \\
\text { non-pyramid }\end{array}$ & $\begin{array}{l}-0.00141 \\
(0.00215)\end{array}$ & $\begin{array}{l}-0.00163 \\
(0.00213)\end{array}$ & $\begin{array}{c}0.00248 \\
(0.00415)\end{array}$ & $\begin{array}{c}0.00245 \\
(0.00414)\end{array}$ & $\begin{array}{c}0.00177 \\
(0.00406)\end{array}$ & $\begin{array}{c}0.00176 \\
(0.00406)\end{array}$ \\
\hline $\begin{array}{l}d \text { Constraint } \times d \text { Block-owned } \\
\text { pyramid } \times \text { PPostCrisis }\end{array}$ & $\begin{array}{l}-0.00225 \\
(0.00305)\end{array}$ & $\begin{array}{l}0.000414 \\
(0.00413)\end{array}$ & $\begin{array}{l}-0.00507 \\
(0.00371)\end{array}$ & $\begin{array}{l}-0.00412 \\
(0.00513)\end{array}$ & $\begin{array}{c}0.00218 \\
(0.00425)\end{array}$ & $\begin{array}{l}-0.00114 \\
(0.00523)\end{array}$ \\
\hline $\begin{array}{l}d \text { Constraint } \times d \text { Block-owned } \\
\text { non-pyramid } \times \text { dPostCrisis }\end{array}$ & $\begin{array}{c}0.00232 \\
(0.00299)\end{array}$ & $\begin{array}{c}0.00467 \\
(0.00348)\end{array}$ & $\begin{array}{l}0.000551 \\
(0.00452)\end{array}$ & $\begin{array}{c}0.00143 \\
(0.00483)\end{array}$ & $\begin{array}{l}-0.000611 \\
(0.00527)\end{array}$ & $\begin{array}{l}-0.00379 \\
(0.00572)\end{array}$ \\
\hline $\begin{array}{l}d \text { Constraint } \times \text { Leverage } \times \\
d \text { PostCrisis }\end{array}$ & & $\begin{array}{l}-0.00961 \\
(0.00783)\end{array}$ & & $\begin{array}{c}-0.00381 \\
(0.0121)\end{array}$ & & $\begin{array}{c}0.0135 \\
(0.0110)\end{array}$ \\
\hline Additional control variables & $\mathrm{Y}$ & $\mathrm{Y}$ & $\mathrm{Y}$ & $\mathrm{Y}$ & $\mathrm{Y}$ & $\mathrm{Y}$ \\
\hline Year and industry FE & $\mathrm{Y}$ & $\mathrm{Y}$ & $\mathrm{Y}$ & $\mathrm{Y}$ & $\mathrm{Y}$ & $\mathrm{Y}$ \\
\hline Observations & 2,338 & 2,338 & 2,237 & 2,237 & 2,523 & 2,523 \\
\hline R-squared & 0.183 & 0.184 & 0.280 & 0.280 & 0.248 & 0.248 \\
\hline
\end{tabular}




\section{(Table 3 continued)}

This table shows regressions explaining the dividend payouts by the operating company for all firms. The independent variable is Dividends over Total assets of the listed operating company. The dummy variable $d$ Block-owned pyramid is equal to one if the company has a blockholder (control of $20 \%$ of more of shares in the operating company) and if the company's ownership structure contains at least one holding company. The dummy variable $d$ Block-owned-no pyramid is equal to one if the company has a blockholder (control of $20 \%$ of more of shares in the operating company) but no pyramidal holding company.

The dummy $d$ PostCrisis is equal to one for the years 2009-2011. If the capital structure of a pyramidal entity is unknown, its value is replaced by the average of all the holdings in the same pyramid (in both measures of pyramidal leverage).

In Panel B, three variables of exposure to financial distress are added and their interactions with $d$ Block-owned pyramid, $d$ Block-owned-no pyramid and $d$ PostCrisis are reported. In columns (1) and (2), the measure for financial distress is the interest coverage ratio; in columns (3) and (4), the measure for financial distress is Net debt/EBITDA, and in columns (5) and (6), the measure for financial distress is the Leverage ratio (Total (financial) debt over Total assets). In addition to the variables of Panel $\mathrm{A}$, the triple interaction terms $d$ Constraint $\times d$ Block-owned pyramid $\times$ dPostCrisis and $d$ Constraint $\times$ $d$ Block-owned non- pyramid $\times d$ PostCrisis are included. Six industry dummies and year dummies are always included. Panel B includes the same set of variables as Panel A and hence, in addition to the reported variables, the following control variables: $\operatorname{Ln}$ (Total assets), Cash and cash equivalents, Operating risk, and Sales Growth. Since we include year dummies, the dummy variable $d$ PostCrisis for the three post-crisis years 2009-2001 is not included and only appears in the interaction terms. Robust standard errors in parentheses. ${ }^{* *} p<0.01,{ }^{* *} p<0.05,{ }^{*} p<0.1$. See Tables 1 and 2 for all variable definitions. 
Table 4: Determinants of dividend payouts for pyramid-controlled firms

Panel A: Baseline regressions

\begin{tabular}{|c|c|c|c|c|c|c|}
\hline \multicolumn{4}{|c|}{ Pyramidal leverage (average) } & \multicolumn{3}{|c|}{ Pyramidal leverage (equivalent) } \\
\hline Variables & $\begin{array}{c}(1) \\
\text { Div / TA }\end{array}$ & $\begin{array}{c}(2) \\
\text { Div / TA }\end{array}$ & $\begin{array}{c}(3) \\
\text { Div / TA }\end{array}$ & $\begin{array}{c}(4) \\
\text { Div / TA }\end{array}$ & $\begin{array}{c}(5) \\
\operatorname{Div} / \mathrm{TA} \\
\end{array}$ & $\begin{array}{c}(6) \\
\operatorname{Div} / \mathrm{TA}\end{array}$ \\
\hline Pyramidal Leverage & $\begin{array}{l}-0.00748^{*} \\
(0.00440)\end{array}$ & $\begin{array}{l}-0.00664 \\
(0.00468)\end{array}$ & $\begin{array}{l}-0.00665 \\
(0.00468)\end{array}$ & $\begin{array}{l}-0.00490 \\
(0.00553)\end{array}$ & $\begin{array}{l}-0.00347 \\
(0.00564)\end{array}$ & $\begin{array}{l}-0.00348 \\
(0.00570)\end{array}$ \\
\hline $\begin{array}{l}\text { Pyramidal Leverage } \times \\
d \text { PostCrisis }\end{array}$ & $\begin{array}{l}0.0146^{* *} \\
(0.00716)\end{array}$ & $\begin{array}{l}0.0156^{* *} \\
(0.00733)\end{array}$ & $\begin{array}{l}0.0155^{* *} \\
(0.00725)\end{array}$ & $\begin{array}{c}0.0111^{*} \\
(0.00659)\end{array}$ & $\begin{array}{c}0.0116^{*} \\
(0.00656)\end{array}$ & $\begin{array}{l}0.0115^{*} \\
(0.00656)\end{array}$ \\
\hline Leverage & $\begin{array}{c}-0.0304 * * * \\
(0.00901)\end{array}$ & $\begin{array}{c}-0.0321 * * * \\
(0.0104)\end{array}$ & $\begin{array}{c}-0.0321 * * * \\
(0.0103)\end{array}$ & $\begin{array}{c}-0.0265 * * * \\
(0.0102)\end{array}$ & $\begin{array}{c}-0.0291 * * \\
(0.0113)\end{array}$ & $\begin{array}{c}-0.0291 * * \\
(0.0112)\end{array}$ \\
\hline $\begin{array}{l}\text { Leverage } \times \\
d \text { PostCrisis }\end{array}$ & $\begin{array}{l}-0.00666 \\
(0.0129)\end{array}$ & $\begin{array}{l}-0.00370 \\
(0.0150)\end{array}$ & $\begin{array}{l}-0.00356 \\
(0.0152)\end{array}$ & $\begin{array}{l}-0.0149 \\
(0.0151)\end{array}$ & $\begin{array}{l}-0.0120 \\
(0.0172)\end{array}$ & $\begin{array}{l}-0.0119 \\
(0.0174)\end{array}$ \\
\hline $\operatorname{Ln}$ (Total assets) & $\begin{array}{c}0.000769 \\
(0.000640)\end{array}$ & $\begin{array}{c}0.000871 \\
(0.000573)\end{array}$ & $\begin{array}{c}0.000868 \\
(0.000613)\end{array}$ & $\begin{array}{c}0.000745 \\
(0.000637)\end{array}$ & $\begin{array}{c}0.000847 \\
(0.000570)\end{array}$ & $\begin{array}{c}0.000843 \\
(0.000611)\end{array}$ \\
\hline Cash and equivalents & $\begin{array}{c}0.00131 \\
(0.00929)\end{array}$ & $\begin{array}{l}-0.000252 \\
(0.00923)\end{array}$ & $\begin{array}{l}-0.000266 \\
(0.00921)\end{array}$ & $\begin{array}{c}0.00193 \\
(0.00922)\end{array}$ & $\begin{array}{l}0.000694 \\
(0.00913)\end{array}$ & $\begin{array}{l}0.000659 \\
(0.00911)\end{array}$ \\
\hline$d$ Loss & $\begin{array}{l}0.00857^{*} \\
(0.00454)\end{array}$ & $\begin{array}{c}0.0104 * \\
(0.00544)\end{array}$ & $\begin{array}{c}0.0104 * \\
(0.00554)\end{array}$ & $\begin{array}{l}0.00853^{*} \\
(0.00464)\end{array}$ & $\begin{array}{c}0.0104^{*} \\
(0.00558)\end{array}$ & $\begin{array}{c}0.0105^{*} \\
(0.00569)\end{array}$ \\
\hline Operating risk & $\begin{array}{c}0.0601 \\
(0.0438)\end{array}$ & $\begin{array}{c}0.0615 \\
(0.0483)\end{array}$ & $\begin{array}{c}0.0611 \\
(0.0488)\end{array}$ & $\begin{array}{c}0.0584 \\
(0.0433)\end{array}$ & $\begin{array}{c}0.0593 \\
(0.0478)\end{array}$ & $\begin{array}{c}0.0591 \\
(0.0484)\end{array}$ \\
\hline Sales growth & $\begin{array}{l}-0.00145 \\
(0.00335)\end{array}$ & $\begin{array}{l}-0.00166 \\
(0.00348)\end{array}$ & $\begin{array}{l}-0.00166 \\
(0.00348)\end{array}$ & $\begin{array}{l}-0.00113 \\
(0.00342)\end{array}$ & $\begin{array}{l}-0.00133 \\
(0.00355)\end{array}$ & $\begin{array}{l}-0.00134 \\
(0.00356)\end{array}$ \\
\hline Control wedge & $\begin{array}{c}-0.00058 * * \\
(0.00026)\end{array}$ & $\begin{array}{l}-0.00055^{*} \\
(0.00028)\end{array}$ & $\begin{array}{c}-0.00055^{* *} \\
(0.00027)\end{array}$ & $\begin{array}{l}-0.00055 \\
(0.00034)\end{array}$ & $\begin{array}{c}-0.00057 * \\
(0.00034)\end{array}$ & $\begin{array}{l}-0.00057 * \\
(0.00033)\end{array}$ \\
\hline Tobin's Q & $\begin{array}{c}0.00821 * * \\
(0.00347)\end{array}$ & $\begin{array}{c}0.00642 * * \\
(0.00298)\end{array}$ & $\begin{array}{c}0.00641 * * \\
(0.00298)\end{array}$ & $\begin{array}{c}0.00814 * * \\
(0.00346)\end{array}$ & $\begin{array}{c}0.00631 * * \\
(0.00298)\end{array}$ & $\begin{array}{c}0.00631 * * \\
(0.00298)\end{array}$ \\
\hline $\mathrm{ROA}$ & $\begin{array}{l}0.135 * * \\
(0.0589)\end{array}$ & $\begin{array}{l}0.159 * * \\
(0.0802)\end{array}$ & $\begin{array}{l}0.159 * * \\
(0.0802)\end{array}$ & $\begin{array}{l}0.134 * * \\
(0.0597)\end{array}$ & $\begin{array}{c}0.159 * \\
(0.0812)\end{array}$ & $\begin{array}{c}0.159^{*} \\
(0.0812)\end{array}$ \\
\hline Annual share turnover & $\begin{array}{l}-0.00126 \\
(0.00201)\end{array}$ & & $\begin{array}{l}0.000139 \\
(0.00207)\end{array}$ & $\begin{array}{l}-0.00128 \\
(0.00210)\end{array}$ & & $\begin{array}{l}0.000110 \\
(0.00215)\end{array}$ \\
\hline $\begin{array}{l}\text { Ret. earnings/Total } \\
\text { equity }\end{array}$ & & $\begin{array}{l}0.000362 \\
(0.00305)\end{array}$ & $\begin{array}{l}0.000401 \\
(0.00311)\end{array}$ & & $\begin{array}{l}0.000545 \\
(0.00300)\end{array}$ & $\begin{array}{l}0.000565 \\
(0.00306)\end{array}$ \\
\hline Year and industry FE & $\mathrm{Y}$ & Y & $\mathrm{Y}$ & $\mathrm{Y}$ & Y & $\mathrm{Y}$ \\
\hline Observations & 1,172 & 1,121 & 1,120 & 1,172 & 1,121 & 1,120 \\
\hline R-squared & 0.325 & 0.319 & 0.318 & 0.323 & 0.317 & 0.317 \\
\hline
\end{tabular}


(Table 4 continued) Panel B: Interaction of pyramidal leverage and operating company financial constraints

\begin{tabular}{|c|c|c|c|c|c|c|}
\hline & \multicolumn{3}{|c|}{ Pyramidal leverage (average) } & \multicolumn{3}{|c|}{ Pyramidal leverage (equivalent) } \\
\hline Variables & $\begin{array}{c}(1) \\
\text { Div / TA }\end{array}$ & $\begin{array}{c}(2) \\
\text { Div / TA }\end{array}$ & $\begin{array}{c}(3) \\
\operatorname{Div} / \mathrm{TA} \\
\end{array}$ & $\begin{array}{c}(4) \\
\text { Div / TA }\end{array}$ & $\begin{array}{c}(5) \\
\text { Div / TA }\end{array}$ & $\begin{array}{c}(6) \\
\text { Div / TA }\end{array}$ \\
\hline Pyramidal Leverage & $\begin{array}{l}-0.00341 \\
(0.00370)\end{array}$ & $\begin{array}{l}-0.00646 \\
(0.00437)\end{array}$ & $\begin{array}{l}-0.00665 \\
(0.00469)\end{array}$ & $\begin{array}{l}-0.00398 \\
(0.00433)\end{array}$ & $\begin{array}{l}-0.00275 \\
(0.00551)\end{array}$ & $\begin{array}{l}-0.00357 \\
(0.00569)\end{array}$ \\
\hline $\begin{array}{l}\text { Pyramidal Leverage } \times \\
d \text { PostCrisis }\end{array}$ & $\begin{array}{l}0.00845^{*} \\
(0.00511)\end{array}$ & $\begin{array}{l}0.0209 * * \\
(0.00978)\end{array}$ & $\begin{array}{c}0.0160^{*} \\
(0.00820)\end{array}$ & $\begin{array}{l}0.0111 * * \\
(0.00523)\end{array}$ & $\begin{array}{l}0.0148 * * \\
(0.00732)\end{array}$ & $\begin{array}{c}0.00989 \\
(0.00622)\end{array}$ \\
\hline Leverage & $\begin{array}{c}-0.0218 * * * \\
(0.00754)\end{array}$ & $\begin{array}{c}-0.0346^{* * *} \\
(0.0127)\end{array}$ & $\begin{array}{c}-0.0321 * * * \\
(0.0103)\end{array}$ & $\begin{array}{c}-0.0187 * * * \\
(0.00647)\end{array}$ & $\begin{array}{c}-0.0323 * * \\
(0.0137)\end{array}$ & $\begin{array}{c}-0.0291 * * \\
(0.0112)\end{array}$ \\
\hline Leverage $\times d$ PostCrisis & $\begin{array}{l}-0.00294 \\
(0.0133)\end{array}$ & $\begin{array}{l}-0.00356 \\
(0.0170)\end{array}$ & $\begin{array}{l}-0.00272 \\
(0.0162)\end{array}$ & $\begin{array}{l}-0.00786 \\
(0.0145)\end{array}$ & $\begin{array}{l}-0.0105 \\
(0.0216)\end{array}$ & $\begin{array}{l}-0.0198 \\
(0.0236)\end{array}$ \\
\hline Interest Coverage Ratio & $\begin{array}{c}0.00007 \\
(0.00005)\end{array}$ & & & $\begin{array}{c}0.00007 \\
(0.00005)\end{array}$ & & \\
\hline $\begin{array}{l}d \text { Interest Coverage Ratio } \times \\
\text { Pyramidal Lev. } \times d \text { PostCrisis }\end{array}$ & $\begin{array}{l}-0.00469 \\
(0.00824)\end{array}$ & & & $\begin{array}{l}-0.00472 \\
(0.00532)\end{array}$ & & \\
\hline Net Debt/EBITDA & & $\begin{array}{l}0.00098^{*} \\
(0.00056)\end{array}$ & & & $\begin{array}{l}0.00103 * \\
(0.00055)\end{array}$ & \\
\hline $\begin{array}{l}d(\text { Net Debt/EBITDA }) \times \\
\text { Pyramidal Lev. } \times d \text { PostCrisis }\end{array}$ & & $\begin{array}{l}-0.0190 * * \\
(0.00886)\end{array}$ & & & $\begin{array}{c}-0.00910 * * \\
(0.00457)\end{array}$ & \\
\hline $\begin{array}{l}d \text { Leverage } \times \\
\text { Pyramidal Lev. } \times d \text { PostCrisis }\end{array}$ & & & $\begin{array}{l}-0.00221 \\
(0.00911)\end{array}$ & & & $\begin{array}{c}0.00680 \\
(0.00725)\end{array}$ \\
\hline$d$ Loss & $\begin{array}{c}0.00627 \\
(0.00417)\end{array}$ & $\begin{array}{c}0.00874 * * \\
(0.00432)\end{array}$ & $\begin{array}{c}0.0104^{*} \\
(0.00558)\end{array}$ & $\begin{array}{c}0.00645 \\
(0.00418)\end{array}$ & $\begin{array}{c}0.00885 * * \\
(0.00440)\end{array}$ & $\begin{array}{c}0.0103^{*} \\
(0.00577)\end{array}$ \\
\hline Control wedge & $\begin{array}{c}-0.00058 * * \\
(0.00026)\end{array}$ & $\begin{array}{c}-0.00064 * * \\
(0.00029)\end{array}$ & $\begin{array}{c}-0.00055^{* *} \\
(0.00027)\end{array}$ & $\begin{array}{c}-0.00062 * * \\
(0.00027)\end{array}$ & $\begin{array}{c}-0.00075 * * \\
(0.00034)\end{array}$ & $\begin{array}{l}-0.00055^{*} \\
(0.00032)\end{array}$ \\
\hline Tobin's Q & $\begin{array}{c}0.00130 \\
(0.00215)\end{array}$ & $\begin{array}{l}0.00567^{*} \\
(0.00302)\end{array}$ & $\begin{array}{r}0.00640 * * \\
(0.00298)\end{array}$ & $\begin{array}{c}0.00131 \\
(0.00215)\end{array}$ & $\begin{array}{l}0.00558^{*} \\
(0.00302)\end{array}$ & $\begin{array}{r}0.00633^{* *} \\
(0.00299)\end{array}$ \\
\hline ROA & $\begin{array}{l}0.0962 * \\
(0.0553)\end{array}$ & $\begin{array}{c}0.234 * * * \\
(0.0880)\end{array}$ & $\begin{array}{l}0.159 * * \\
(0.0804)\end{array}$ & $\begin{array}{l}0.0947 * \\
(0.0559)\end{array}$ & $\begin{array}{c}0.234 * * * \\
(0.0887)\end{array}$ & $\begin{array}{c}0.158 * \\
(0.0816)\end{array}$ \\
\hline Annual share turnover & $\begin{array}{c}0.00128 \\
(0.00179)\end{array}$ & $\begin{array}{l}0.000764 \\
(0.00250)\end{array}$ & $\begin{array}{l}0.000117 \\
(0.00209)\end{array}$ & $\begin{array}{c}0.00127 \\
(0.00182)\end{array}$ & $\begin{array}{c}0.000719 \\
(0.00260)\end{array}$ & $\begin{array}{c}0.000281 \\
(0.00225)\end{array}$ \\
\hline Ret. earnings/Total equity & $\begin{array}{c}0.00102 \\
(0.00210)\end{array}$ & $\begin{array}{l}-0.00026 \\
(0.00322)\end{array}$ & $\begin{array}{c}0.00036 \\
(0.00315)\end{array}$ & $\begin{array}{c}0.00096 \\
(0.00212)\end{array}$ & $\begin{array}{c}0.00021 \\
(0.00313)\end{array}$ & $\begin{array}{c}0.00072 \\
(0.00311)\end{array}$ \\
\hline Additional control variables & $\mathrm{Y}$ & $\mathrm{Y}$ & $\mathrm{Y}$ & $\mathrm{Y}$ & Y & $\mathrm{Y}$ \\
\hline Year and industry FE & $\mathrm{Y}$ & $\mathrm{Y}$ & $\mathrm{Y}$ & $\mathrm{Y}$ & $\mathrm{Y}$ & $\mathrm{Y}$ \\
\hline Observations & 1,042 & 1,006 & 1,120 & 1,042 & 1,006 & 1,120 \\
\hline R-squared & 0.296 & 0.386 & 0.318 & 0.298 & 0.384 & 0.317 \\
\hline
\end{tabular}

Table 4 shows regressions explaining the dividend payouts by the operating company for firms controlled by a pyramid. The independent variable is Dividends over Total assets of the listed operating company. Pyramidal leverage is measured by average leverage in equations (1) to (3), and equivalent leverage in equations (4) to (6) of each panel. Both panels include an identical set of control variables. Panel A reports the full set of control variables except for the six industry dummies (not shown). Panel B includes the same set of variables and hence, in addition to the reported variables, the following control variables: $\quad \operatorname{Ln}$ (Total assets), Cash and cash equivalents, Operating risk, and Sales growth. If the capital structure of a pyramidal entity is unknown, its value is replaced by the average of all the holdings in the same pyramid (in both measures of pyramidal leverage). Six industry dummies and year dummies are always included. Since we include year dummies, the dummy variable $d$ PostCrisis for the three post-crisis years 2009-2001 is not included and only appears in the interaction terms. Robust standard errors in parentheses. ${ }^{* *} p<0.01, * * p<0.05, * p<0.1$. See Tables 1 and 2 for all variable definitions. 
Table 5: Summary statistics pyramid-owned companies and holding companies

Panel A: Summary statistics for all holding companies per period, pre-crisis and post-crisis period

\begin{tabular}{|c|c|c|c|c|c|c|c|c|c|c|c|}
\hline & \multicolumn{4}{|c|}{$\begin{array}{l}\text { Pre-crisis period }(2000- \\
\text { 2008) }\end{array}$} & \multicolumn{4}{|c|}{ Post-crisis period (2009-2011) } & \multicolumn{3}{|c|}{$\begin{array}{l}\text { Tests pre-crisis v. } \\
\text { post-crisis }\end{array}$} \\
\hline & \multicolumn{3}{|c|}{ Media } & \multirow[b]{2}{*}{ \# obs } & \multicolumn{2}{|r|}{ Media } & & & \multirow[b]{2}{*}{$t$-test } & \multirow[b]{2}{*}{$\begin{array}{l}\text { sign rank } \\
\text { test }\end{array}$} & \multirow[b]{2}{*}{ \#obs } \\
\hline & Mean & $\mathrm{n}$ & Stdev & & Mean & $\mathrm{n}$ & & & & & \\
\hline Dividends received / Total assets & 0.046 & 0.011 & 0.092 & 1205 & 0.036 & 0.008 & 0.061 & 476 & 0.117 & 0.336 & 69 \\
\hline Interest expense / Total assets & 0.012 & 0.007 & 0.017 & 1186 & 0.015 & 0.006 & 0.042 & 434 & 0.262 & 0.595 & 64 \\
\hline Total debt / Total assets & 0.191 & 0.099 & 0.220 & 1182 & 0.209 & 0.128 & 0.229 & 432 & 0.099 & 0.145 & 64 \\
\hline LT debt / Total assets & 0.158 & 0.017 & 0.215 & 1182 & 0.208 & 0.124 & 0.228 & 432 & 0.001 & 0.002 & 64 \\
\hline Cash / Total assets & 0.079 & 0.014 & 0.131 & 1212 & 0.065 & 0.007 & 0.131 & 435 & 0.792 & 0.640 & 65 \\
\hline Investment ratio & 1.049 & 0.635 & 1.453 & 1049 & 1.092 & 0.767 & 1.394 & 396 & 0.585 & 0.060 & 59 \\
\hline Investment ratio, capped between 0 and 1 & 0.594 & 0.666 & 0.393 & 1097 & 0.615 & 0.763 & 0.400 & 409 & 0.273 & 0.280 & 60 \\
\hline Ln (Total assets) & 5.623 & 5.295 & 2.522 & 1207 & 5.679 & 5.248 & 2.388 & 434 & 0.000 & 0.000 & 64 \\
\hline$d$ Next is Ultimate Owner & 0.513 & 1.000 & 0.500 & 2596 & 0.469 & - & 0.499 & 868 & 0.008 & 0.021 & 84 \\
\hline Ownership stake & 0.607 & 0.533 & 0.278 & 2596 & 0.634 & 0.557 & 0.282 & 868 & 0.360 & 0.062 & 84 \\
\hline $\begin{array}{l}\text { Div. received / (Interest exp. } \times \text { Investment } \\
\text { ratio) }\end{array}$ & 82.84 & 2.75 & 317.56 & 956 & 32.294 & 3.492 & 164.95 & 338 & 0.647 & 0.240 & 49 \\
\hline Div. received / (Interest expense $\times$ & 91.59 & 3.091 & 323.72 & 932 & 52.386 & 3.725 & 238.72 & 332 & 0.794 & 0.219 & 47 \\
\hline Investment ratio capped between 0 and 1 ) & & & & & & & & & & & \\
\hline
\end{tabular}


Panel B: Summary statistics of all holding companies, pre- and post-crisis, with sample split by leverage ratio (Total debt / Total assets)

Observations with leverage ratio in the top quartile

\begin{tabular}{|c|c|c|c|c|c|c|c|c|}
\hline & \multicolumn{4}{|c|}{ Pre-crisis period (2000-2008) } & \multicolumn{4}{|c|}{ Post-crisis period (2009-2011) } \\
\hline & Mean & Median & Stdev & \# obs & Mean & Median & Stdev & \# obs \\
\hline Dividends received / Total assets & 0.033 & 0.008 & 0.084 & 256 & 0.033 & 0.016 & 0.040 & 92 \\
\hline Interest expense / Total assets & 0.024 & 0.023 & 0.015 & 292 & 0.031 & 0.024 & 0.069 & 108 \\
\hline Total debt / Total assets & 0.523 & 0.507 & 0.122 & 296 & 0.540 & 0.526 & 0.122 & 108 \\
\hline LT debt / Total assets & 0.458 & 0.477 & 0.196 & 296 & 0.538 & 0.522 & 0.124 & 108 \\
\hline Cash / Total assets & 0.067 & 0.017 & 0.096 & 296 & 0.048 & 0.010 & 0.096 & 108 \\
\hline Investment ratio & 0.562 & 0.325 & 0.724 & 264 & 0.735 & 0.663 & 0.630 & 99 \\
\hline Investment ratio, capped between 0 and 1 & 0.436 & 0.325 & 0.353 & 276 & 0.583 & 0.642 & 0.376 & 103 \\
\hline $\operatorname{Ln}$ (Total assets) & 6.850 & 6.970 & 2.134 & 296 & 6.754 & 6.839 & 2.305 & 107 \\
\hline$d$ Next is Ultimate Owner & 0.402 & - & 0.491 & 296 & 0.435 & - & 0.498 & 108 \\
\hline Ownership stake & 0.701 & 0.669 & 0.290 & 296 & 0.688 & 0.675 & 0.278 & 108 \\
\hline Div. received / (Interest exp. $\times$ Investment ratio) & 5.458 & 1.284 & 29.054 & 236 & 7.824 & 1.488 & 26.933 & 85 \\
\hline Div. received / (Interest expense $\times$ & 9.031 & 1.566 & 34.440 & 232 & 8.392 & 2.061 & 27.348 & 82 \\
\hline Investment ratio capped between 0 and 1 ) & & & & & & & & \\
\hline
\end{tabular}

Observations with leverage ratio in the three bottom quartiles

\begin{tabular}{|c|c|c|c|c|c|c|c|c|}
\hline & \multicolumn{4}{|c|}{ Pre-crisis period (2000-2008) } & \multicolumn{4}{|c|}{ Post-crisis period (2009-2011) } \\
\hline & Mean & Median & Stdev & \# obs & Mean & Median & Stdev & $\#$ obs \\
\hline Dividends received / Total assets & 0.051 & 0.016 & 0.089 & 762 & 0.036 & 0.007 & 0.062 & 287 \\
\hline Interest expense / Total assets & 0.008 & 0.003 & 0.016 & 874 & 0.009 & 0.002 & 0.024 & 323 \\
\hline Total debt / Total assets & 0.080 & 0.018 & 0.102 & 886 & 0.098 & 0.011 & 0.127 & 324 \\
\hline LT debt / Total assets & 0.057 & 0.000 & 0.094 & 886 & 0.098 & 0.009 & 0.126 & 324 \\
\hline Cash / Total assets & 0.079 & 0.014 & 0.133 & 886 & 0.072 & 0.005 & 0.141 & 324 \\
\hline Investment ratio & 1.156 & 0.786 & 1.440 & 763 & 1.201 & 0.789 & 1.553 & 294 \\
\hline Investment ratio, capped between 0 and 1 & 0.642 & 0.818 & 0.393 & 796 & 0.622 & 0.805 & 0.407 & 303 \\
\hline $\operatorname{Ln}$ (Total assets) & 5.274 & 5.033 & 2.500 & 882 & 5.336 & 5.114 & 2.320 & 324 \\
\hline$d$ Next is Ultimate Owner & 0.616 & 1.000 & 0.487 & 886 & 0.497 & - & 0.501 & 324 \\
\hline Ownership stake & 0.547 & 0.511 & 0.266 & 886 & 0.552 & 0.511 & 0.269 & 324 \\
\hline Div. received $/($ Interest exp. $\times$ Investment ratio $)$ & 111.283 & 4.964 & 357.186 & 573 & 42.780 & 4.396 & 207.594 & 189 \\
\hline $\begin{array}{l}\text { Div. received / (Interest expense } \times \\
\text { Investment ratio capped) }\end{array}$ & 113.672 & 5.374 & 346.443 & 558 & 77.240 & 4.401 & 308.130 & 186 \\
\hline
\end{tabular}

This table provides summary statistics of pyramidal-owned companies and of their holding companies prior to the crisis, for the entire sample period, but only for companies with complete observation of the capital structure of all holding companies in the pyramid. The measures of pyramidal leverage, average leverage and equivalent leverage, assume that missing observation have the same capital structure as the observed entities in each pyramid. Robust standard errors in parentheses. Investment ratio is the part of all asset of a holding company that is constituted by the ultimate owners' equity stake in the pyramidal entity directly below, or in the listed operating company if the listed operating company is placed immediately below the holding entity (investment ratios are lagged by one period, and capped within the interval $[0,1]$ ). Dividends received is the amount of dividends received by the holding entity (in euros). Dividends Received/Total assets is dividends received, divided by the total assets of the holding entity. See Tables 1 and 2 for the definitions of all other variables. In Panel A, the column $t$-test reports paired two sided $t$-tests of differences between the mean of the 2000-2008 period and of the 2009-2011 period. The column sign rank test is a Wilcoxon signed rank test of differences between the median of the 2000-2008 period and of the 2009-2011 period. To include an observation in the test, we require that there be at least 4 observations in the pre-crisis period $(2000-2008)$ and at least 2 observations in the post-crisis period (2009 - 2011), explaining the low observation count and power of the tests for differences. 
Table 6: Determinants of dividend passed through to dominant owners, based on pyramidal leverage

Panel A: Summary statistics of dividend pass-through

\begin{tabular}{|c|c|c|c|c|c|c|}
\hline & \multicolumn{3}{|c|}{ Pre-crisis $(2000-2008)$} & \multicolumn{3}{|c|}{ Post-crisis (2009 -2011) } \\
\hline & Mean & Median & \# obs & Mean & Median & \# obs \\
\hline Dividend pass-through (DivPassThrough) & 0.5959 & 0.6636 & 527 & 0.7073 & 0.8338 & 146 \\
\hline Pyramid leverage (average), lagged & 0.1217 & 0.0029 & 527 & 0.1300 & 0.0012 & 146 \\
\hline Pyramid leverage (equivalent), lagged & 0.3794 & 0.3684 & 527 & 0.4071 & 0.3640 & 146 \\
\hline Number of layers & 2.4573 & 2.0000 & 527 & 2.6370 & 2.0000 & 146 \\
\hline Proportion missing entities & 0.3060 & 0.0000 & 527 & 0.3279 & 0.0000 & 146 \\
\hline
\end{tabular}

Panel B: Regression analysis of dividend pass-through

\begin{tabular}{|c|c|c|c|c|}
\hline & \multicolumn{2}{|c|}{ Pyramidal leverage not lagged } & \multicolumn{2}{|c|}{ Pyramidal leverage lagged } \\
\hline & $\begin{array}{c}(1) \\
\text { DivPassThrough }\end{array}$ & $\begin{array}{c}(2) \\
\text { DivPassThrough }\end{array}$ & $\begin{array}{c}\text { (3) } \\
\text { DivPassThrough }\end{array}$ & $\begin{array}{c}(4) \\
\text { DivPassThrough }\end{array}$ \\
\hline Number of layers & $\begin{array}{c}-0.0710 * * * \\
(0.0117)\end{array}$ & $\begin{array}{c}-0.0614 * * * \\
(0.0126)\end{array}$ & $\begin{array}{c}-0.0767 * * * \\
(0.0108)\end{array}$ & $\begin{array}{c}-0.0636 * * * \\
(0.0147)\end{array}$ \\
\hline Pyramid leverage (average) & $\begin{array}{l}-0.346^{* *} \\
(0.162)\end{array}$ & & $\begin{array}{l}-0.283 \\
(0.179)\end{array}$ & \\
\hline Pyramidal leverage (equivalent) & & $\begin{array}{l}-0.278 * * * \\
(0.0880)\end{array}$ & & $\begin{array}{c}-0.267 * * * \\
(0.0984)\end{array}$ \\
\hline $\begin{array}{l}\text { Pyramid leverage (average) } \times \\
d \text { PostCrisis }\end{array}$ & $\begin{array}{c}0.00794 \\
(0.207)\end{array}$ & & $\begin{array}{l}-0.130 \\
(0.216)\end{array}$ & \\
\hline $\begin{array}{l}\text { Pyramidal leverage (equivalent) } \times \\
d \text { PostCrisis }\end{array}$ & & $\begin{array}{c}0.196 \\
(0.122)\end{array}$ & & $\begin{array}{c}0.101 \\
(0.120)\end{array}$ \\
\hline Observations & 872 & 872 & 673 & 673 \\
\hline R-squared & 0.145 & 0.143 & 0.173 & 0.174 \\
\hline
\end{tabular}

This table analyzes the fraction of the dividends that the ultimate owner in a pyramid-controlled company receives through the pyramidal structure, as a function of the combined debt service obligation of the pyramidal layer(s). DivPassThrough (or dividend passed through) is the fraction of the dividends that the operating company makes available to the dominant owner that is eventually received by the dominant owner, i.e. dividends received by the dominant owner / (dominant owner's combined ownership in the operating company $\times$ dividend paid by operating company). The measure of pyramidal leverage of the pyramid of holding companies is average leverage in equation (1) and (3), and equivalent leverage in equations (2) and (4). If the capital structure of a pyramidal entity is unknown, its value is replaced by the average of all the holdings in the same pyramid. If the capital structure of none of the holding companies can be observed, pyramidal leverage is assumed to be zero (in both measures of pyramidal leverage). Robust standard errors in parentheses. ${ }^{* * *} p<0.01,{ }^{* *} p<0.05, * p<$ 0.1 . See Tables 1 and 2 for other variable definitions. 
Table 7: Determinants of dividend payouts for all firms - alternative definition of pyramidal leverage

\begin{tabular}{|c|c|c|c|c|c|c|}
\hline \multirow{3}{*}{$\begin{array}{l}\text { Pyramidal leverage, missing }=0 \\
\text { Variables }\end{array}$} & \multicolumn{3}{|c|}{ Pyramidal leverage (average) } & \multicolumn{3}{|c|}{ Pyramidal leverage (equivalent) } \\
\hline & (1) & $(2)$ & (3) & (4) & $(5)$ & (6) \\
\hline & Div / TA & Div / TA & Div / TA & Div / TA & Div / TA & Div / TA \\
\hline Pyramidal Leverage & $\begin{array}{l}-0.00200 \\
(0.00369)\end{array}$ & $\begin{array}{l}-0.00580 \\
(0.00464)\end{array}$ & $\begin{array}{l}-0.00570 \\
(0.00496)\end{array}$ & $\begin{array}{l}-0.00295 \\
(0.00425)\end{array}$ & $\begin{array}{l}-0.00214 \\
(0.00591)\end{array}$ & $\begin{array}{l}-0.00270 \\
(0.00604)\end{array}$ \\
\hline Pyramidal Leverage $\times d$ PostCrisis & $\begin{array}{c}0.00685 \\
(0.00502)\end{array}$ & $\begin{array}{l}0.0203 * * \\
(0.00999)\end{array}$ & $\begin{array}{c}0.0151 * \\
(0.00837)\end{array}$ & $\begin{array}{c}0.0101 * \\
(0.00513)\end{array}$ & $\begin{array}{c}0.0144 * \\
(0.00774)\end{array}$ & $\begin{array}{c}0.00915 \\
(0.00644)\end{array}$ \\
\hline Leverage & $\begin{array}{c}-0.0216 * * * \\
(0.00754)\end{array}$ & $\begin{array}{c}-0.0344 * * * \\
(0.0127)\end{array}$ & $\begin{array}{c}-0.0318 * * * \\
(0.0103)\end{array}$ & $\begin{array}{c}-0.0192 * * * \\
(0.00640)\end{array}$ & $\begin{array}{c}-0.0326^{* *} \\
(0.0141)\end{array}$ & $\begin{array}{c}-0.0294 * * \\
(0.0116)\end{array}$ \\
\hline Leverage $\times d$ PostCrisis & $\begin{array}{l}-0.00294 \\
(0.0134)\end{array}$ & $\begin{array}{l}-0.00378 \\
(0.0168)\end{array}$ & $\begin{array}{l}-0.00253 \\
(0.0159)\end{array}$ & $\begin{array}{l}-0.00725 \\
(0.0146)\end{array}$ & $\begin{array}{l}-0.0103 \\
(0.0219)\end{array}$ & $\begin{array}{l}-0.0195 \\
(0.0238)\end{array}$ \\
\hline Interest Coverage Ratio & $\begin{array}{c}0.00007 \\
(0.00005)\end{array}$ & & & $\begin{array}{c}0.00007 \\
(0.00005)\end{array}$ & & \\
\hline $\begin{array}{l}d \text { Interest Coverage Ratio } \times \\
\text { Pyramidal Lev. } \times d \text { PostCrisis }\end{array}$ & $\begin{array}{l}-0.00533 \\
(0.00913)\end{array}$ & & & $\begin{array}{l}-0.00487 \\
(0.00561)\end{array}$ & & \\
\hline Net Debt/EBITDA & & $\begin{array}{l}0.000982 * \\
(0.000554)\end{array}$ & & & $\begin{array}{c}0.00104 * \\
(0.000547)\end{array}$ & \\
\hline $\begin{array}{l}d(\text { Net Debt } / \text { EBITDA }) \times \\
\text { Pyramidal Lev. } \times d \text { PostCrisis }\end{array}$ & & $\begin{array}{l}-0.0209 * * \\
(0.00918)\end{array}$ & & & $\begin{array}{c}-0.00936^{* *} \\
(0.00466)\end{array}$ & \\
\hline $\begin{array}{l}d \text { Leverage } \times \text { Pyramidal Lev. } \times \\
d \text { PostCrisis }\end{array}$ & & & $\begin{array}{l}-0.00308 \\
(0.00973)\end{array}$ & & & $\begin{array}{c}0.00686 \\
(0.00734)\end{array}$ \\
\hline$d$ Loss & $\begin{array}{c}0.00637 \\
(0.00415)\end{array}$ & $\begin{array}{c}0.00889 * * \\
(0.00433)\end{array}$ & $\begin{array}{c}0.0106^{*} \\
(0.00557)\end{array}$ & $\begin{array}{c}0.00657 \\
(0.00417)\end{array}$ & $\begin{array}{c}0.00893 * * \\
(0.00439)\end{array}$ & $\begin{array}{c}0.0104 * \\
(0.00576)\end{array}$ \\
\hline Control wedge & $\begin{array}{c}-0.00059 * * \\
(0.000262)\end{array}$ & $\begin{array}{c}-0.000642 * * \\
(0.000285)\end{array}$ & $\begin{array}{c}-0.000546^{* *} \\
(0.000275)\end{array}$ & $\begin{array}{c}-0.000643 * * \\
(0.000273)\end{array}$ & $\begin{array}{c}-0.000763 * * \\
(0.000349)\end{array}$ & $\begin{array}{r}-0.000567 * \\
(0.000327)\end{array}$ \\
\hline Tobin's Q & $\begin{array}{c}0.00125 \\
(0.00214)\end{array}$ & $\begin{array}{l}0.00562 * \\
(0.00302)\end{array}$ & $\begin{array}{c}0.00635^{* *} \\
(0.00298)\end{array}$ & $\begin{array}{c}0.00127 \\
(0.00215)\end{array}$ & $\begin{array}{l}0.00556^{*} \\
(0.00302)\end{array}$ & $\begin{array}{r}0.00630 * * \\
(0.00299)\end{array}$ \\
\hline ROA & $\begin{array}{l}0.0968^{*} \\
(0.0552)\end{array}$ & $\begin{array}{l}0.235 * * * \\
(0.0881)\end{array}$ & $\begin{array}{l}0.160 * * \\
(0.0804)\end{array}$ & $\begin{array}{l}0.0956^{*} \\
(0.0559)\end{array}$ & $\begin{array}{c}0.234 * * * \\
(0.0885)\end{array}$ & $\begin{array}{c}0.159^{*} \\
(0.0814)\end{array}$ \\
\hline Annual share turnover & $\begin{array}{c}0.00122 \\
(0.00178)\end{array}$ & $\begin{array}{l}0.000774 \\
(0.00249)\end{array}$ & $\begin{array}{c}0.00005 \\
(0.00208)\end{array}$ & $\begin{array}{c}0.00119 \\
(0.00181)\end{array}$ & $\begin{array}{l}0.000687 \\
(0.00259)\end{array}$ & $\begin{array}{l}0.000220 \\
(0.00223)\end{array}$ \\
\hline Ret. Earnings/TE & $\begin{array}{c}0.00104 \\
(0.00210)\end{array}$ & $\begin{array}{l}-0.000243 \\
(0.00322)\end{array}$ & $\begin{array}{l}0.000371 \\
(0.00314)\end{array}$ & $\begin{array}{l}0.000978 \\
(0.00212)\end{array}$ & $\begin{array}{l}0.000238 \\
(0.00310)\end{array}$ & $\begin{array}{l}0.000763 \\
(0.00309)\end{array}$ \\
\hline Additional control variables & $\mathrm{Y}$ & $\mathrm{Y}$ & Y & $\mathrm{Y}$ & $\mathrm{Y}$ & $\mathrm{Y}$ \\
\hline Year and industry FE & $\mathrm{Y}$ & $\mathrm{Y}$ & $\mathrm{Y}$ & $\mathrm{Y}$ & $\mathrm{Y}$ & $\mathrm{Y}$ \\
\hline Observations & 1,042 & 1,006 & 1,120 & 1,042 & 1,006 & 1,120 \\
\hline R-squared & 0.296 & 0.386 & 0.318 & 0.298 & 0.384 & 0.317 \\
\hline
\end{tabular}

Table 7 reproduces the estimation of Table 4, Panel B, with an alternative measure of pyramidal leverage: for both average leverage and equivalent leverage, instead of assuming that missing holding entities have the mean leverage, we now conservatively set their leverage to zero. Regressions explain the dividend payouts by the operating company for firms controlled by a pyramid. The independent variable is Dividends over Total Assets. Pyramidal leverage is measured by average leverage in equations (1) to (3), and equivalent leverage in equations (4) to (6) of each panel. Both panels include the same set of independent variables as does Table 4. The additional control variables not reported in the Table are : $\operatorname{Ln}($ Assets), Cash and cash equivalents, Operating risk, and Sales Growth. Six industry dummies and year dummies are always included. Since we include year dummies, the dummy variable $d$ PostCrisis for the three post-crisis years 2009-2001 is not included and only appears in the interaction terms. Robust standard errors in parentheses. *** $p<0.01, * * p<0.05,^{*} p<0.1$. See Tables 1 and 2 for all variable definitions. 
Table 8: Determinants of dividends pass-through - alternative definition of pyramidal leverage

Pyramidal leverage, missing $=0$ Pyramidal leverage not lagged

Pyramidal leverage lagged

(1)

(2)

(3)

(4)

DivPassThrough DivPassThrough DivPassThrough DivPassThrough

Number of layers

$-0.0716^{* * *}$

$-0.0610 * * *$

$-0.0765 * * *$

$-0.0621 * * *$

(0.0116)

(0.0127)

(0.0107)

(0.0148)

Pyramid leverage (average)

$-0.354 * *$

$-0.330^{*}$

(0.167)

(0.187)

Pyramidal leverage (equivalent)

$-0.282 * * *$

$-0.286^{* * *}$

(0.0904)

(0.101)

Pyramid leverage (average) $\times d$ PostCrisis

$-0.101$

$-0.124$

(0.214)

(0.232)

Pyramidal leverage (equivalent) $\times$

0.172

0.0981

$d$ PostCrisis

(0.126)

(0.123)

\begin{tabular}{lcccc}
\hline Observations & 872 & 872 & 673 & 673 \\
R-squared & 0.145 & 0.143 & 0.173 & 0.174 \\
\hline
\end{tabular}

In this table, we reproduce the estimation of Table 6 Panel B with an alternative measure of pyramidal leverage; for average leverage and equivalent leverage, instead of assuming that missing holding entities have the mean leverage, we now conservatively set their leverage to zero. Robust standard errors in parentheses. ${ }^{* * *} p<0.01,{ }^{*} p<0.05, * p<0.1$. See Tables 1 and 2 for variable definitions. 
Figure 1: Stylized example

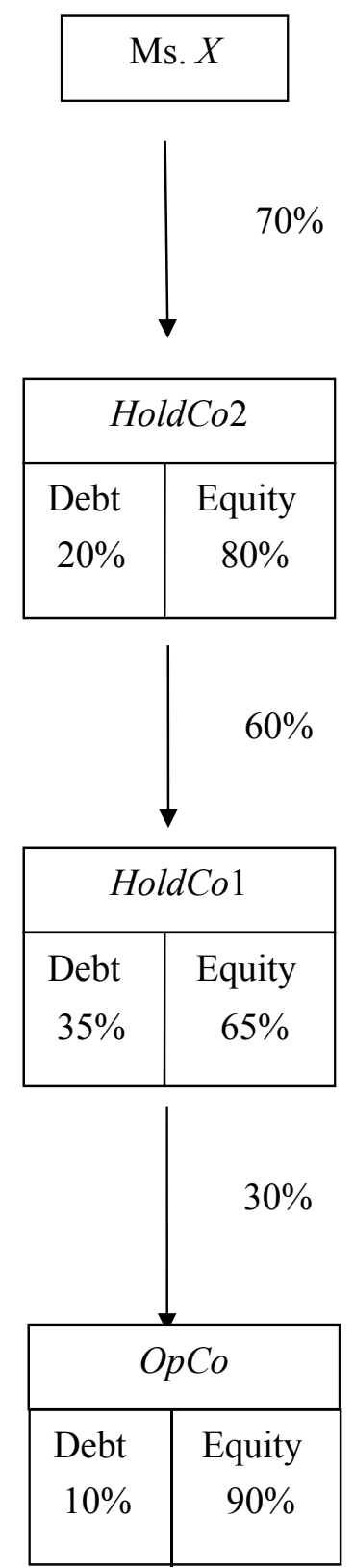

Stylized example in which Ms. $X$ holds a $70 \%$ equity stake in HoldCo2, HoldCo2 holds a $60 \%$ stake in HoldCo1, and HoldCo1 holds a $30 \%$ stake in OpCo. HoldCo2 is financed with $80 \%$ equity and $20 \%$ debt, HoldCo1 with $65 \%$ equity and $35 \%$ debt, and OpCo with $90 \%$ equity and $10 \%$ debt. 


\section{Appendix A: Full Algorithms for the Equivalent Leverage and Control Wedge}

To correctly identify dominant owners and their control and cash flow rights, we first identify for each company all direct equity stakes in excess of $5 \%$. We then determine whether the entities owning these blocks of shares are directly or indirectly owned by other shareholders or entities with stakes in excess of $5 \%$. This process is iterated until we reach the ultimate owners. ${ }^{26}$ For the set of $N$ entities found in this process, including ultimate owners and the operating company, we denote the equity stake of entity $i$ in entity $j$ by $\alpha_{i j}$. Let $\mathbf{A}=\left(\alpha_{\mathrm{ij}}\right)$ be the $N \times N$-matrix of all shareholdings in the pyramid, including those of ultimate owners. We place the operating company in the last position, so that $\alpha_{i N}$ denotes entity $i$ 's stake in the operating company. Let $\mathbf{a}_{\boldsymbol{k}}$ be the column vector of direct stockholdings of ultimate shareholder $k$ in the $N$ entities. Then the cash flow rights $\mathbf{f}_{\boldsymbol{k}}$ of ultimate shareholder $k$ in all entities are consistently defined by the vector: ${ }^{27}$

$$
\mathbf{f}_{\boldsymbol{k}}=(\mathbf{I}-\mathbf{A})^{-1} \mathbf{a}_{k},
$$

where $\mathbf{I}$ is the identity matrix. The $N$-th element of this vector, $f_{k N}$, denotes shareholder $k$ 's level of cash flow rights in the operating firm. For example, if the pyramid consists only of a single control chain of vertically stacked entities (as in the Section 2.2 example), this algorithm determines $f_{k N}$ simply as the product of all ownership stakes along this control chain, $f_{k N}=\prod_{i=k, \ldots, N-1} \alpha_{i, i+1}$. If the ultimate owner is linked to the operating company via multiple but disjointed control chains, the algorithm will calculate the product of ownership stakes along each control chain and then add these products to obtain $f_{k N .}{ }^{28}$ Following Almeida et al. (2011), we capture the discontinuous character of control rights by introducing a threshold that indicates the level of control above which the shareholder is said to assume absolute control; we also fix its value at 50\%. Adopting this majority rule, we convert effective control rights (i.e. the sum of direct and indirect voting rights in a company) of greater than $50 \%$ in any entity into full control of $100 \%$. The other stakes are then allocated zero control rights. Formally, we redefine the control right stake of owner $k$ in entity $j$ as:

$$
c_{k j}=\left\{\begin{array}{ccc}
1 & \text { if } & f_{k j}>0.5 \\
0 & \text { if } & \exists i \neq k, f_{i j}>0.5 \\
f_{k j} & & \text { otherwise }
\end{array}\right.
$$

This algorithm must be applied iteratively, by replacing $f_{k j}$ by $c_{k j}$ for all ultimate owners and repeating the algorithm until the procedure converges to a vector $\mathbf{c}_{\boldsymbol{k}}$, which in our sample it does in all cases after

\footnotetext{
${ }^{26}$ For ultimate owners identified in this procedure, we also record share stakes smaller than 5\% that they hold in the operating company or in another entity.

27 This procedure is used and explained e.g. in Almeida et al. (2011) and Chapelle and Szafarz (2005). It follows the classical example of input-output analysis and can handle any level of pyramidal complexity.

${ }^{28}$ The matrix approach is only needed to properly define ownership rights in more complex pyramidal structures, such as cross-holdings, and it handles any level of complexity consistently. For the implementation of the matrix algorithm, we use a consistent and conventional procedure to resolve possible conflicts and to assign the appropriate stake to the applicable control chain, by checking whether a particular stake occurs twice and then stopping tracing.
} 
only a few rounds. ${ }^{29}$ After the iterative process converges, $c_{k N}$, the $N$-th element in the vector $\mathbf{c}_{\boldsymbol{k}}$, denotes shareholder $k$ 's level of control rights in the operating firm. ${ }^{30}$ We define the control wedge of owner $k$ as:

$$
\text { Control Wedge } \mathrm{e}_{k}=\frac{c_{k N}}{f_{k N}} .
$$

We calculate equivalent leverage in complex pyramids as follows. Let $l_{i}$ denote the leverage ratio (1 equity/total assets) of entity $i\left(l_{i}=0\right.$ for ultimate owners). We define $\beta_{i j}=\alpha_{i j} \cdot\left(1-l_{i}\right)$ as the debtadjusted cash flow right of entity $i$ after receiving dividends from entity $j$ and paying its debt service. Let $\mathbf{B}=\left(\beta_{\mathrm{ij}}\right)$ be the $N \times N$-matrix of all debt-adjusted cash flow rights in the pyramid, and $\mathbf{b}_{\boldsymbol{k}}$ as the vector of debt-adjusted cash flow rights of shareholder $k$. Following the same procedure as for unadjusted cash flow rights, we obtain the vector $\mathbf{d}_{\boldsymbol{k}} \equiv(\mathbf{I}-\mathbf{B})^{-1} \mathbf{b}_{\boldsymbol{k}}$, where the $N$-th element $d_{k N}$ denotes shareholder $k$ 's level of debt-adjusted cash flow rights in the operating firm. That is, we decompose $f_{k N}$ introduced above into two components: $f_{k N}-d_{k N}$ is the part that is consumed by debt service obligations, and $d_{k N}$ is the part that is left for the ultimate owner. Taking into account that we need to scale by the aggregate cash flow rights, we define the equivalent leverage of ultimate owner $k$ as:

$$
\text { Equivalent pyramidal leverage }{ }_{k}=\frac{f_{k N}-d_{k N}}{f_{k N}} \text {. }
$$

To provide some intuition for this matrix expression, in the case where there are just two distinct control chains (but there are no crossholdings or loops), this expression can be written as:

$$
\begin{aligned}
& \text { Equivalent pyramidal leverage }_{k}=
\end{aligned}
$$

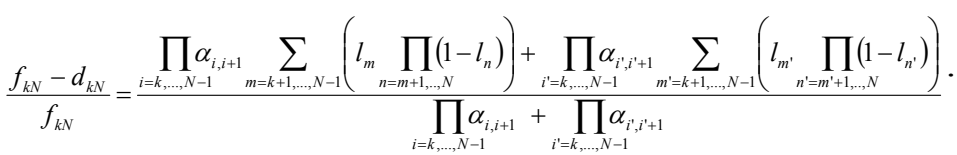

Obviously, in the case of a single control chain (as in the Section 2.2 example), there is a single product of equity stakes, $\prod_{i=k, \ldots, N-1} \alpha_{i, i+1}$, that cancels out from both the numerator and denominator, and we are left with the expression given in Section 2.2.

\footnotetext{
29 The iteration is only needed if an ultimate owner $k$ has several, direct or indirect, holdings in an entity $j$; if their sum $f_{k j}$ exceeds 0.5 , the algorithm will convert $f_{k j}$ to $c_{k j}=1$, which in turn may lead the combined holdings of owner $k$ in another entity $m$ to exceed 0.5 and hence trigger the next round of conversions, etc.

30 It is instructive to compare this measure of control rights to the widely used weakest link rule (see La Porta, Lopez-deSilanes, and Shleifer, 1999). In a single control chain such as in the Figure 1 example, the weakest link equates control rights with the smallest equity stake along the chain, thus implicitly converting the control rights of all other links to $100 \%$ similar to our rule. Since this conversion, however, also applies to equity stakes smaller than $50 \%$ but larger than the weakest link, the weakest link rule often leads to assigning larger control rights to dominant owners than our rule does. The control rights assigned by the weakest link rule are not always larger in the case of multiple and complex control chains.
} 



\section{Internet Appendix}

to

"Blockholder Leverage and Payout Policy:

Evidence from French Holding Companies”

October 2019 
Table IA.1: Investment regressions

Pyramidal leverage, missing $=0$

\begin{tabular}{|c|c|c|}
\hline VARIABLES & $\begin{array}{c}(1) \\
\text { Capex }\end{array}$ & $\begin{array}{c}(2) \\
\text { Capex }\end{array}$ \\
\hline Tobin's Q & $\begin{array}{c}0.0706^{* * *} \\
(0.0176)\end{array}$ & $\begin{array}{c}0.0697 * * * \\
(0.0176)\end{array}$ \\
\hline Cash flow & $\begin{array}{l}0.495 * * \\
(0.201)\end{array}$ & $\begin{array}{l}0.491 * * \\
(0.204)\end{array}$ \\
\hline Dividend / Cash flow & $\begin{array}{l}-0.101 * * \\
(0.0467)\end{array}$ & $\begin{array}{c}-0.0990 * * \\
(0.0481)\end{array}$ \\
\hline Pyramidal leverage (average) & $\begin{array}{l}-0.0245 \\
(0.0698)\end{array}$ & \\
\hline Pyramidal leverage (equivalent) & & $\begin{array}{l}-0.0315 \\
(0.0412)\end{array}$ \\
\hline Pyramidal leverage (average) $* d$ PostCrisis & $\begin{array}{c}0.128 \\
(0.0812)\end{array}$ & \\
\hline Pyramidal leverage (equivalent) $* d$ PostCrisis & & $\begin{array}{c}0.0343 \\
(0.0585)\end{array}$ \\
\hline $\begin{array}{l}\text { Other control variables } \\
\text { Year and industry FE }\end{array}$ & $\begin{array}{l}\mathrm{Y} \\
\mathrm{Y}\end{array}$ & $\begin{array}{l}\mathrm{Y} \\
\mathrm{Y}\end{array}$ \\
\hline $\begin{array}{l}\text { Observations } \\
\text { R-squared }\end{array}$ & $\begin{array}{l}1,087 \\
16.6 \%\end{array}$ & $\begin{array}{l}1,087 \\
16.4 \%\end{array}$ \\
\hline
\end{tabular}

In this table, we test whether there is a significant change in investment expenditures (capex) after the crisis, as a function of pyramidal leverage. Robust standard errors in parentheses. ${ }^{* *} p<0.01,{ }^{*} p<0.05, * p<0.1$. See Tables 1 and 2 for variable definitions. 
Table IA.2: Alternative dividend variables

\begin{tabular}{|c|c|c|c|c|c|c|}
\hline Variables & $\begin{array}{c}(1) \\
\text { Div/Sales }\end{array}$ & $\begin{array}{c}(2) \\
\text { Div/Sales }\end{array}$ & $\begin{array}{c}(3) \\
\text { Div/Sales }\end{array}$ & $\begin{array}{c}(4) \\
\text { Div/CF }\end{array}$ & $\begin{array}{c}(5) \\
\text { Div/CF }\end{array}$ & $\begin{array}{c}(6) \\
\mathrm{Div} / \mathrm{CF}\end{array}$ \\
\hline Pyramidal leverage & $\begin{array}{c}-0.0421 * * * \\
(0.0150)\end{array}$ & $\begin{array}{c}-0.0425 * * \\
(0.0163)\end{array}$ & $\begin{array}{c}-0.0411 * * \\
(0.0159)\end{array}$ & $\begin{array}{c}-0.0333 \\
(0.0394)\end{array}$ & $\begin{array}{l}-0.0224 \\
(0.0416)\end{array}$ & $\begin{array}{l}-0.0231 \\
(0.0415)\end{array}$ \\
\hline Leverage & $\begin{array}{l}-0.0116 \\
(0.0322)\end{array}$ & $\begin{array}{l}-0.0181 \\
(0.0332)\end{array}$ & $\begin{array}{l}-0.0150 \\
(0.0334)\end{array}$ & $\begin{array}{c}-0.213 * * * \\
(0.0605)\end{array}$ & $\begin{array}{c}-0.188^{* * *} \\
(0.0663)\end{array}$ & $\begin{array}{c}-0.188 * * * \\
(0.0663)\end{array}$ \\
\hline Ln (assets) & $\begin{array}{c}0.00552 \\
(0.00367)\end{array}$ & $\begin{array}{c}0.00446 \\
(0.00332)\end{array}$ & $\begin{array}{c}0.00547 \\
(0.00373)\end{array}$ & $\begin{array}{l}0.0168 * * \\
(0.00701)\end{array}$ & $\begin{array}{l}0.0170^{* *} \\
(0.00672)\end{array}$ & $\begin{array}{c}0.0166^{* *} \\
(0.00745)\end{array}$ \\
\hline Cash and equivalents & $\begin{array}{c}0.0950 \\
(0.0612)\end{array}$ & $\begin{array}{c}0.0771 \\
(0.0646)\end{array}$ & $\begin{array}{c}0.0851 \\
(0.0632)\end{array}$ & $\begin{array}{l}0.185 \\
(0.137)\end{array}$ & $\begin{array}{c}0.198 \\
(0.134)\end{array}$ & $\begin{array}{c}0.197 \\
(0.134)\end{array}$ \\
\hline$d$ Loss & $0.0184^{*}$ & $0.0197^{*}$ & $0.0211^{*}$ & -0.0295 & -0.0187 & -0.0168 \\
\hline Operating risk & $\begin{array}{l}(0.0103) \\
0.393^{* *}\end{array}$ & $\begin{array}{c}(0.0113) \\
0.423 *\end{array}$ & $\begin{array}{c}(0.0115) \\
0.438^{*}\end{array}$ & $\begin{array}{c}(0.0401) \\
0.162\end{array}$ & $\begin{array}{c}(0.0439) \\
0.423\end{array}$ & $\begin{array}{c}(0.0447) \\
0.410\end{array}$ \\
\hline & $(0.196)$ & $(0.222)$ & $(0.226)$ & $(0.388)$ & $(0.474)$ & $(0.480)$ \\
\hline Growth & -0.0244 & -0.0264 & -0.0275 & $-0.0589^{*}$ & $-0.0602 *$ & $-0.0606^{*}$ \\
\hline & $(0.0177)$ & $(0.0178)$ & $(0.0181)$ & $(0.0352)$ & $(0.0362)$ & $(0.0361)$ \\
\hline Control wedge & 0.00498 & 0.00515 & 0.00500 & 0.00493 & 0.00484 & 0.00487 \\
\hline & $(0.00475)$ & $(0.00483)$ & $(0.00474)$ & $(0.00590)$ & $(0.00583)$ & $(0.00583)$ \\
\hline Tobin's Q & 0.00495 & -0.0009 & -0.0004 & 0.0114 & 0.00920 & 0.00873 \\
\hline & $(0.0132)$ & $(0.0104)$ & $(0.0104)$ & $(0.0136)$ & $(0.0141)$ & $(0.0141)$ \\
\hline ROA & $0.328 * * *$ & $0.383 * * *$ & $0.383 * * *$ & 0.112 & 0.0217 & 0.0263 \\
\hline & $(0.114)$ & $(0.143)$ & $(0.143)$ & $(0.213)$ & $(0.323)$ & $(0.324)$ \\
\hline Pyramidal leverage $\times d$ PostCrisis & $0.0409 * *$ & $0.0394 * *$ & $0.0416^{* *}$ & $0.111^{*}$ & $0.111^{*}$ & $0.107^{*}$ \\
\hline & $(0.0187)$ & $(0.0183)$ & $(0.0184)$ & $(0.0624)$ & $(0.0631)$ & $(0.0628)$ \\
\hline Leverage $\times d$ PostCrisis & 0.00630 & 0.00754 & 0.0112 & & & \\
\hline & $(0.0398)$ & $(0.0437)$ & $(0.0432)$ & & & \\
\hline Liquidity & $-0.0193 *$ & & -0.0158 & -0.0136 & & 0.00871 \\
\hline & $(0.0106)$ & & $(0.0107)$ & $(0.0297)$ & & $(0.0283)$ \\
\hline Retained earnings / Total equity & & $\begin{array}{l}-0.00017 \\
(0.00848)\end{array}$ & $\begin{array}{l}-0.00074 \\
(0.00838)\end{array}$ & & $\begin{array}{c}0.0419 \\
(0.0303)\end{array}$ & $\begin{array}{c}0.0436 \\
(0.0305)\end{array}$ \\
\hline Year and industry FE & Y & $\mathrm{Y}$ & Y & Y & Y & Y \\
\hline Observations & 1,151 & 1,101 & 1,100 & 1,126 & 1,077 & 1,076 \\
\hline R-squared & 0.134 & 0.142 & 0.142 & 0.133 & 0.141 & 0.142 \\
\hline
\end{tabular}

This table follows our main regression of Table 4, Panel A, but uses alternative measures for the left-hand side variable: Dividend/Sales (Div/Sales) in columns (1) to (3), and Dividend/Cash Flow (Div/CF) in columns (4) to (6). Pyramidal leverage used in the regressions reported in this table is pyramidal leverage (average). Robust standard errors in parentheses. ${ }^{* * *} p<$ $0.01, * * p<0.05, * p<0.1$. See Tables 1 and 2 for variable definitions. 
Table IA.3 : Summary statistics pyramid-owned companies and holding companies

Panel A: Summary statistics pyramid-owned companies per period, pyramids with complete info only

\begin{tabular}{|c|c|c|c|c|c|c|c|c|}
\hline & \multicolumn{4}{|c|}{ Pre-crisis period $(2000-2008)$} & \multicolumn{4}{|c|}{ Post-crisis period (2009-2011) } \\
\hline & Mean & Median & Stdev & \# obs & Mean & Median & Stdev & \# obs \\
\hline \multicolumn{9}{|l|}{ Financials } \\
\hline Dividend / Total assets & 0.020 & 0.012 & 0.040 & 540 & 0.014 & 0.007 & 0.023 & 184 \\
\hline Dividend / Cash flows & 0.201 & 0.158 & 0.224 & 517 & 0.186 & 0.120 & 0.236 & 178 \\
\hline $\operatorname{Ln}$ (Total assets) & 6.464 & 6.442 & 2.160 & 540 & 6.796 & 6.899 & 2.110 & 184 \\
\hline Leverage ratio & 0.229 & 0.232 & 0.162 & 540 & 0.242 & 0.224 & 0.182 & 184 \\
\hline Sales growth & 0.117 & 0.100 & 0.302 & 502 & 0.000 & 0.033 & 0.290 & 177 \\
\hline Operational risk & 0.036 & 0.022 & 0.038 & 540 & 0.039 & 0.028 & 0.041 & 184 \\
\hline Loss & 0.119 & - & 0.324 & 540 & 0.234 & - & 0.424 & 184 \\
\hline Capex & 0.295 & 0.269 & 0.250 & 473 & 0.270 & 0.223 & 0.240 & 167 \\
\hline Tobin's Q & 1.477 & 1.205 & 0.856 & 539 & 1.163 & 1.031 & 0.406 & 184 \\
\hline Cash flow & 0.083 & 0.075 & 0.100 & 540 & 0.063 & 0.055 & 0.075 & 184 \\
\hline Direct ownership & 0.372 & 0.326 & 0.202 & 540 & 0.389 & 0.341 & 0.220 & 184 \\
\hline Control wedge & 2.215 & 1.659 & 2.262 & 540 & 2.648 & 1.769 & 3.951 & 184 \\
\hline Pyramidal leverage (average) & 0.198 & 0.136 & 0.293 & 539 & 0.229 & 0.165 & 0.271 & 184 \\
\hline Pyramidal leverage (equivalent) & 0.435 & 0.409 & 0.327 & 539 & 0.483 & 0.489 & 0.308 & 184 \\
\hline Number of layers & 2.620 & 2.000 & 1.608 & 540 & 2.728 & 2.000 & 1.650 & 184 \\
\hline Proportion of missing entities & - & - & - & 540 & - & - & - & 184 \\
\hline \multicolumn{9}{|c|}{ Financial constraints, stock market liquidity, firm life cycle } \\
\hline Interest coverage ratio & 28.180 & 5.098 & 86.716 & 491 & 35.522 & 4.980 & 113.271 & 173 \\
\hline Net debt / EBITDA & 1.943 & 1.226 & 2.704 & 482 & 2.456 & 1.314 & 3.303 & 161 \\
\hline Annual share turnover & 0.235 & 0.098 & 0.361 & 540 & 0.314 & 0.086 & 0.492 & 183 \\
\hline Retained earnings / Total equity & 0.535 & 0.622 & 0.382 & 519 & 0.591 & 0.701 & 0.403 & 174 \\
\hline
\end{tabular}

Panel B: Summary statistics holding companies in pyramids, pyramids with complete information only

\begin{tabular}{|c|c|c|c|c|c|c|}
\hline & \multicolumn{3}{|c|}{ Pre-crisis (2000-2008) } & \multicolumn{3}{|c|}{ Post-crisis (2009-2011) } \\
\hline & Mean & Median & \# obs & Mean & Median & \# obs \\
\hline Dividends received / Total assets & 0.041 & 0.013 & 770 & 0.033 & 0.007 & 281 \\
\hline Interest expense / Total assets & 0.012 & 0.007 & 770 & 0.012 & 0.005 & 281 \\
\hline Total debt / Total assets & 0.190 & 0.102 & 770 & 0.196 & 0.080 & 281 \\
\hline LT debt / Total assets & 0.164 & 0.031 & 770 & 0.195 & 0.063 & 281 \\
\hline Cash / Total assets & 0.069 & 0.012 & 770 & 0.059 & 0.007 & 281 \\
\hline Investment ratio & 1.012 & 0.651 & 770 & 1.136 & 0.813 & 281 \\
\hline Investment ratio, capped between 0 and 1 & 0.597 & 0.651 & 770 & 0.639 & 0.813 & 281 \\
\hline $\operatorname{Ln}$ (Total assets) & 5.641 & 5.207 & 770 & 5.620 & 5.175 & 281 \\
\hline$d$ Next is Ultimate Owner & 0.626 & 1.000 & 770 & 0.534 & 1.000 & 281 \\
\hline Ownership stake & 0.565 & 0.517 & 770 & 0.583 & 0.553 & 281 \\
\hline
\end{tabular}

In this table, we provide additional summary statistics on pyramidal-owned companies and of their holding companies for the entire sample period, in addition to the summary statistics provided in Table 5. Panel A and Panel B of this table only include holding companies for companies with complete observation of the pyramidal variables, in contrast to Table 5, Panel A and Panel B, that includes all companies, including companies with incomplete observation of the pyramidal entities. See Tables 1 and 2 for variable definitions. 
Table IA.4: Summary statistics pyramid-owned companies per period, pyramids with complete information only, with sample split by pyramidal average leverage

\begin{tabular}{|c|c|c|c|c|c|c|c|c|c|c|c|c|c|c|c|c|}
\hline & \multicolumn{8}{|c|}{ Observations with top quartile pyramidal average leverage } & \multicolumn{8}{|c|}{ Observations with bottom three quartiles pyramidal average leverage } \\
\hline & \multicolumn{4}{|c|}{ Pre-crisis $(2000-2008)$} & \multicolumn{4}{|c|}{ Post-crisis (2009-2011) } & \multicolumn{4}{|c|}{ Pre-crisis (2000-2008) } & \multicolumn{4}{|c|}{ Post-crisis (2009-2011) } \\
\hline & Mean & Median & Stdev & \# obs & Mean & Median & Stdev & \# obs & Mean & Median & Stdev & \# obs & Mean & Median & Stdev & \# obs \\
\hline Dividend / Total assets & 0.022 & 0.012 & 0.058 & 135 & 0.021 & 0.011 & 0.037 & 46 & 0.019 & 0.012 & 0.033 & 404 & 0.011 & 0.007 & 0.014 & 138 \\
\hline Ln (Total assets) & 6.921 & 7.255 & 2.408 & 135 & 6.862 & 6.759 & 2.112 & 46 & 6.321 & 6.206 & 2.045 & 404 & 6.774 & 6.919 & 2.117 & 138 \\
\hline Leverage ratio & 0.256 & 0.258 & 0.149 & 135 & 0.238 & 0.230 & 0.189 & 46 & 0.220 & 0.218 & 0.166 & 404 & 0.244 & 0.220 & 0.180 & 138 \\
\hline Sales growth & 0.112 & 0.123 & 0.326 & 126 & 0.058 & 0.056 & 0.158 & 43 & 0.120 & 0.096 & 0.294 & 375 & -0.018 & 0.028 & 0.319 & 134 \\
\hline Operational risk & 0.039 & 0.022 & 0.044 & 135 & 0.050 & 0.039 & 0.043 & 46 & 0.034 & 0.021 & 0.036 & 404 & 0.035 & 0.022 & 0.040 & 138 \\
\hline Loss & 0.156 & - & 0.364 & 135 & 0.239 & - & 0.431 & 46 & 0.104 & - & 0.306 & 404 & 0.232 & - & 0.424 & 138 \\
\hline Capex & 0.291 & 0.281 & 0.260 & 114 & 0.307 & 0.224 & 0.270 & 44 & 0.296 & 0.267 & 0.248 & 359 & 0.257 & 0.213 & 0.228 & 123 \\
\hline Tobin's Q & 1.428 & 1.271 & 0.583 & 135 & 1.216 & 1.072 & 0.425 & 46 & 1.493 & 1.182 & 0.930 & 403 & 1.146 & 1.011 & 0.399 & 138 \\
\hline Cash flow & 0.056 & 0.063 & 0.129 & 135 & 0.056 & 0.055 & 0.063 & 46 & 0.093 & 0.080 & 0.084 & 404 & 0.065 & 0.055 & 0.079 & 138 \\
\hline Dividend / Cash flows & 0.205 & 0.167 & 0.218 & 131 & 0.223 & 0.183 & 0.232 & 46 & 0.200 & 0.154 & 0.226 & 385 & 0.173 & 0.097 & 0.236 & 132 \\
\hline Direct ownership & 0.414 & 0.396 & 0.212 & 135 & 0.440 & 0.341 & 0.251 & 46 & 0.359 & 0.310 & 0.197 & 404 & 0.372 & 0.342 & 0.207 & 138 \\
\hline Control wedge & 1.678 & 1.506 & 0.704 & 135 & 1.482 & 1.159 & 0.719 & 46 & 2.396 & 1.722 & 2.559 & 404 & 3.036 & 1.827 & 4.481 & 138 \\
\hline Pyramidal leverage (average) & 0.522 & 0.470 & 0.426 & 135 & 0.580 & 0.490 & 0.310 & 46 & 0.090 & 0.069 & 0.088 & 404 & 0.111 & 0.096 & 0.105 & 138 \\
\hline $\begin{array}{l}\text { Pyramidal leverage } \\
\text { (equivalent) }\end{array}$ & 0.727 & 0.667 & 0.373 & 135 & 0.766 & 0.738 & 0.269 & 46 & 0.337 & 0.325 & 0.241 & 404 & 0.389 & 0.362 & 0.258 & 138 \\
\hline Number of layers & 2.681 & 2.000 & 1.268 & 135 & 2.609 & 2.000 & 0.977 & 46 & 2.601 & 2.000 & 1.709 & 404 & 2.768 & 2.000 & 1.822 & 138 \\
\hline Proportion of missing entities & - & - & - & 135 & - & - & - & 46 & - & - & - & 404 & - & - & - & 138 \\
\hline Interest coverage ratio & 15.821 & 4.478 & 42.726 & 126 & 25.627 & 7.372 & 55.483 & 45 & 32.586 & 5.787 & 97.178 & 364 & 39.000 & 4.604 & 127.527 & 128 \\
\hline Net debt / EBITDA & 2.166 & 1.775 & 2.083 & 118 & 2.513 & 1.143 & 3.343 & 39 & 1.871 & 0.963 & 2.876 & 364 & 2.437 & 1.362 & 3.304 & 122 \\
\hline Annual share turnover & 0.352 & 0.152 & 0.488 & 135 & 0.445 & 0.078 & 0.654 & 46 & 0.195 & 0.087 & 0.299 & 404 & 0.270 & 0.087 & 0.418 & 137 \\
\hline $\begin{array}{l}\text { Retained earnings / Total } \\
\text { equity }\end{array}$ & 0.427 & 0.432 & 0.397 & 129 & 0.579 & 0.701 & 0.412 & 44 & 0.570 & 0.665 & 0.370 & 390 & 0.596 & 0.699 & 0.402 & 130 \\
\hline
\end{tabular}


Table IA.4 (continued):

Summary statistics pyramid-owned companies per period, pyramids with complete information only, with sample split by pyramidal equivalent leverage

\begin{tabular}{|c|c|c|c|c|c|c|c|c|c|c|c|c|c|c|c|c|}
\hline & \multicolumn{8}{|c|}{ Observations with top quartile pyramidal equivalent leverage } & \multicolumn{8}{|c|}{ Observations with bottom three quartiles pyramidal equivalent leverage } \\
\hline & \multicolumn{4}{|c|}{ Pre-crisis $(2000-2008)$} & \multicolumn{4}{|c|}{ Post-crisis (2009-2011) } & \multicolumn{4}{|c|}{ Pre-crisis $(2000-2008)$} & \multicolumn{4}{|c|}{ Post-crisis (2009-2011) } \\
\hline & Mean & Median & Stdev & \# obs & Mean & Median & Stdev & \# obs & Mean & Median & Stdev & \# obs & Mean & Median & Stdev & \# obs \\
\hline Dividend / Total assets & 0.018 & 0.010 & 0.044 & 135 & 0.009 & 0.003 & 0.013 & 46 & 0.019 & 0.012 & 0.033 & 404 & 0.011 & 0.007 & 0.014 & 138 \\
\hline Ln (Total assets) & 7.590 & 7.755 & 2.295 & 135 & 7.152 & 6.853 & 2.130 & 46 & 6.321 & 6.206 & 2.045 & 404 & 6.774 & 6.919 & 2.117 & 138 \\
\hline Leverage ratio & 0.287 & 0.306 & 0.160 & 135 & 0.329 & 0.342 & 0.219 & 46 & 0.220 & 0.218 & 0.166 & 404 & 0.244 & 0.220 & 0.180 & 138 \\
\hline Sales growth & 0.080 & 0.091 & 0.310 & 127 & -0.053 & 0.009 & 0.326 & 41 & 0.120 & 0.096 & 0.294 & 375 & -0.018 & 0.028 & 0.319 & 134 \\
\hline Operational risk & 0.036 & 0.019 & 0.041 & 135 & 0.045 & 0.036 & 0.046 & 46 & 0.034 & 0.021 & 0.036 & 404 & 0.035 & 0.022 & 0.040 & 138 \\
\hline Loss & 0.141 & - & 0.349 & 135 & 0.326 & - & 0.474 & 46 & 0.104 & - & 0.306 & 404 & 0.232 & - & 0.424 & 138 \\
\hline Capex & 0.275 & 0.264 & 0.245 & 114 & 0.247 & 0.213 & 0.228 & 41 & 0.296 & 0.267 & 0.248 & 359 & 0.257 & 0.213 & 0.228 & 123 \\
\hline Tobin's Q & 1.344 & 1.198 & 0.502 & 135 & 1.107 & 0.994 & 0.294 & 46 & 1.493 & 1.182 & 0.930 & 403 & 1.146 & 1.011 & 0.399 & 138 \\
\hline Cash flow & 0.039 & 0.051 & 0.117 & 135 & 0.032 & 0.031 & 0.058 & 46 & 0.093 & 0.080 & 0.084 & 404 & 0.065 & 0.055 & 0.079 & 138 \\
\hline Dividend / Cash flows & 0.234 & 0.165 & 0.282 & 124 & 0.137 & 0.047 & 0.182 & 45 & 0.200 & 0.154 & 0.226 & 385 & 0.173 & 0.097 & 0.236 & 132 \\
\hline Direct ownership & 0.299 & 0.259 & 0.181 & 135 & 0.359 & 0.323 & 0.243 & 46 & 0.359 & 0.310 & 0.197 & 404 & 0.372 & 0.342 & 0.207 & 138 \\
\hline Control wedge & 3.644 & 2.000 & 3.971 & 135 & 4.385 & 1.687 & 6.677 & 46 & 2.396 & 1.722 & 2.559 & 404 & 3.036 & 1.827 & 4.481 & 138 \\
\hline Pyramidal leverage (average) & 0.431 & 0.342 & 0.459 & 135 & 0.440 & 0.366 & 0.384 & 46 & 0.090 & 0.069 & 0.088 & 404 & 0.111 & 0.096 & 0.105 & 138 \\
\hline $\begin{array}{l}\text { Pyramidal leverage } \\
\text { (equivalent) }\end{array}$ & 0.829 & 0.771 & 0.337 & 135 & 0.861 & 0.810 & 0.209 & 46 & 0.337 & 0.325 & 0.241 & 404 & 0.389 & 0.362 & 0.258 & 138 \\
\hline Number of layers & 3.874 & 3.000 & 1.945 & 135 & 4.043 & 3.000 & 2.573 & 46 & 2.601 & 2.000 & 1.709 & 404 & 2.768 & 2.000 & 1.822 & 138 \\
\hline Proportion of missing entities & - & - & - & 135 & - & - & - & 46 & - & - & - & 404 & - & - & - & 138 \\
\hline Interest coverage ratio & 9.618 & 3.350 & 34.404 & 116 & 8.329 & 2.821 & 19.408 & 43 & 32.586 & 5.787 & 97.178 & 364 & 39.000 & 4.604 & 127.527 & 128 \\
\hline Net debt / EBITDA & 2.868 & 2.292 & 3.277 & 115 & 3.509 & 2.734 & 3.739 & 38 & 1.871 & 0.963 & 2.876 & 364 & 2.437 & 1.362 & 3.304 & 122 \\
\hline Annual share turnover & 0.379 & 0.188 & 0.517 & 135 & 0.267 & 0.030 & 0.417 & 46 & 0.195 & 0.087 & 0.299 & 404 & 0.270 & 0.087 & 0.418 & 137 \\
\hline $\begin{array}{l}\text { Retained earnings / Total } \\
\text { equity }\end{array}$ & 0.382 & 0.365 & 0.440 & 131 & 0.482 & 0.640 & 0.461 & 45 & 0.570 & 0.665 & 0.370 & 390 & 0.596 & 0.699 & 0.402 & 130 \\
\hline
\end{tabular}




\section{Table IA.4 (continued):}

Summary statistics pyramid-owned companies per period, pyramids with complete information only, with sample split by pyramidal equivalent leverage

Note: This table replicates the analysis of Table 5 Panel B, but uses a different breakdown of companies, by distinguishing between the top quartile of firms by pyramidal average or equivalent leverage, and all other firms. This table considers only pyramid-owned companies with complete financial information for all pyramidal entities. In this table, pyramidal leverage variables assume missing ratios $=$ average ratios. See Table 1 and Table 2 for variables definitions. 